\title{
Calorimetry for Safeguards
}

Purposes

DETERMINATION OF PLUTONIUM IN

REACTOR FEED MATERIAL

F. A. O'Hara

J. D. Nutter

W. W. Rodenburg

M. L. Dinsmore

January 5, 1972

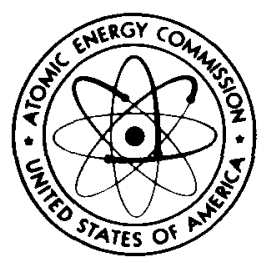

AEC Research and Development Report

\section{MOUND LABORATORY}

Miamisburg, Ohio

operated by

Monsanto

\section{MONSANTO RESEARCH CORPORATION}

a subsidiary of Monsanto Company

for the

\author{
U. S. ATOMIC ENERGY COMMISSION \\ U. S. Government Contract No. AT-33-1-GEN-53
}




\section{DISCLAIMER}

This report was prepared as an account of work sponsored by an agency of the United States Government. Neither the United States Government nor any agency Thereof, nor any of their employees, makes any warranty, express or implied, or assumes any legal liability or responsibility for the accuracy, completeness, or usefulness of any information, apparatus, product, or process disclosed, or represents that its use would not infringe privately owned rights. Reference herein to any specific commercial product, process, or service by trade name, trademark, manufacturer, or otherwise does not necessarily constitute or imply its endorsement, recommendation, or favoring by the United States Government or any agency thereof. The views and opinions of authors expressed herein do not necessarily state or reflect those of the United States Government or any agency thereof. 


\section{DISCLAIMER}

Portions of this document may be illegible in electronic image products. Images are produced from the best available original document. 
MLM- 1798

TI D -4500

UC -15

\title{
Calorimetry for Safeguards Purposes
}

\section{DETERMINATION OF PLUTONIUM IN REACTOR FEED MATERIAL}

\author{
F. A. O'Hara \\ J. D. Nutter \\ W. W. Rodenburg \\ M. L. Dinsmore
}

\section{Issued: January 5,1972}

\section{LEGAL NOTICE}

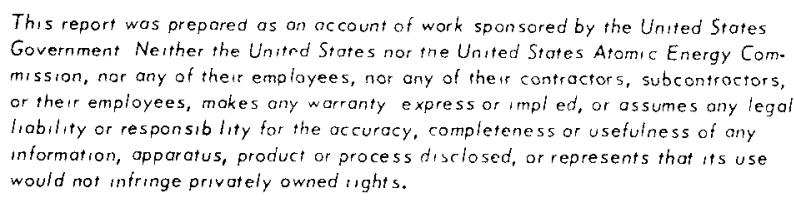

PRINTED IN THE UNITED STATES OF AMERICA

Avallable fro

Natio 3t Teclintcal intertiat on service

U 5 Department of Com rerce

5285 Port Royal Rosd

Spr ngfield Virginia 22151

Price Pristed Copy $\$ 300$. Microfiche $\$ 095$

\section{MONSANTO RESEARCH CORPORATION}

A Subsidiary of Monsanto Company

\section{MOUND LABORATORY}

Miamisburg, Ohio

45342

operated for

\section{UNITED STATES ATOMIC ENERGY COMMISSION \\ US Government Contract No AT-33-1-GEN-53}

This report was prepared as an account of work
sponsored by the United States Government. Neither
the United States nor the United States Atomic Energy
Commission, nor any of their employees, nor any of
their contractors, subcontractors, or their employees,
makes any warranty, express or implied, or assumes any
legal liability or responsibility for the accuracy, com-
pleteness or usefulness of any information, apparatus,
product or process disclosed, or represents that its use
would not infringe privately owned rights.


TABLE OF CONTENTS

Page

FOREWORD

3

$\begin{array}{ll}\text { ABSTRACT } & 4\end{array}$

INTRODUCTION

BACKGROUND

$\begin{array}{ll}\text { THE DESIGN OF RADIONUCLIDE CALORIMETERS } & 10\end{array}$

$\begin{array}{ll}\text { EXPERIMENTAL } & 22\end{array}$

$\begin{array}{ll}\text { RESULTS } & 26\end{array}$

$\begin{array}{ll}\text { CONCLUSIONS } & 35\end{array}$

$\begin{array}{ll}\text { FUTURE PLANS } & 36\end{array}$

$\begin{array}{ll}\text { APPENDIX } & 37\end{array}$

REFERENCES $\quad 42$ 


\section{FOREWORD}

This progress report contains detailed information on the technical contribution made by Mound Laboratory to the Safeguards Program of the U. S. Atomic Energy Commission. Questions regarding information in this report should be directed to Dr. J. D. Nutter or Dr. F. A. O'Hara, Mound Laboratory, Monsanto Research Corporation, Miamisburg, Ohio 45342. 


\begin{abstract}
This report is the first of a series of reports covering work performed at Mound Laboratory at the request of the AEC Office of Safeguards and Materials Management. The purpose of this work is to test the feasibility and applicability of calorimetric assay of radioactive materials involved in the reactor fuel cycle, primarily plutonium.

Included is a brief history of calorimetry, a description of the instrumentation and techniques used, and the results of the calorimetric assay of two reactor-fuel samples. These samples each contained approximately $1 \mathrm{~kg}$ of plutonium oxide feed material with isotopic compositions typical of plutanium from fast breeder reactors and light water reactors.
\end{abstract}




\section{INTRODUCTION}

Early in 1970, the AEC/Office of Safeguards and Materials Management requested Mound Laboratory to determine the feasibility of the calorimetric assay technique for Safeguards situations. The following features are some of the advantages of this technique:

- The assay is nondestructive.

- The calorimetric technique is highly precise and, where the isotopic composition of sample is known, highly accurate.

- Calorimeters can be adapted to an automatic data processing system or operated by a technician.

- The total power of a sample can be determined without sampling or aliquotting.

- Calorimetry can discriminate between the fissile isotopes ${ }^{235} \mathrm{U}$ and ${ }^{239} \mathrm{Pu}$ because of the difference in half-lives.

- The measurements are based on primary electrical standards which in general are more reliable than counting standards. 


\section{BACKGROUND}

A calorimeter is an instrument for measuring heat. All chemical and physical processes involve energy changes. The direct evaluation of these changes is the goal of the methods of calorimetry. Calorimetric measurements are almost completely based on temperature measurements, and in many cases involve problems of temperature control.

The modern calorimetric method is essentially the measurement of the amount of electrical energy necessary to duplicate the thermal efiect accompanying a physical or chemical change. Modern calorimetric dal a are, therefore, primarily expressed in units of electrical energy.

Radionuclide calorimeters are used to measure materials emitting alphd, beta, or gamma radiation. The principal difference between radionuclids calorimetry and other fields of calorimetry is the emission of an almost constant rate of heat (power) due to absorption of the emitted particles by the calorimeter during decay of the isotope present in the sample. In other types of calorimeters, a burst of heat is usually measured. Calorimetry was one of the earliest techniques used for the quantitative determination of radioactivity. In 1903, Pierre Curie and A. Laborde were able to estimate the energy released from radium bromide by utilizing a calorimeter. ${ }^{1}$ Rutherford and Barnes, also in 1903, determined the heat produced by $1 \mathrm{~g}$ of radium in equilibrium with its short half-life daughters.2

If a sample of radioactive material is known to contain only one radioisotope, the following equation applies:

$$
\mathrm{W}=\frac{2.11933 \times 10^{3} \mathrm{Qm}}{\mathrm{T}^{\frac{1}{2}} \mathrm{~A}}
$$

where

$$
\begin{aligned}
& \mathrm{W}=\text { watts measured in calorimeter; } \\
& \mathrm{Q}=\text { disintegration energy of isotope in million electron volts (MeV), } \\
& \mathrm{m}=\text { mass of isotope present in grams; } \\
& \mathrm{T} \frac{1}{2}=\text { half-1ife of the isotope in years; } \\
& \mathrm{A}=\text { atomic weight of isotope in grams. }
\end{aligned}
$$

If the disintegration energy and the half-life of the isotope are known, the mass of the isotope present in the sample can be determined. Tine calorimeter thus serves as an assay instrument. If the mass and dijin:tegration energy are known, calorimetry gives the power and hence the half-life may be determined. If the half-life is short enough, the 
change with time of the power of the sample may be measured calorimetrically and is sufficient to determine the half-life of the nuclide. The most precisely known half-1ives have been determined by this method.

Equation (1) can also be expressed in the form:

$$
W=1.60210 \times 10^{-13} \mathrm{Q} \lambda \mathrm{N},
$$

or

$$
W=1.60210 \times 10^{-13} Q \lambda N_{0} e^{-\lambda t},
$$

where

$$
\begin{aligned}
& \mathrm{N}=\text { number of atoms of isotope at time, } t, \\
& \mathrm{~N}_{\mathrm{O}}=\text { number of atoms of isotope at time, } t=0, \\
& \lambda=\text { decay constant of isotope in second }
\end{aligned}
$$

In actual practice, equations (1) and (2) can be simplified to

$$
\mathrm{W}=\mathrm{mF} \text {, }
$$

where

$$
\begin{aligned}
& \mathrm{m}=\text { grams of isotope } \\
& \mathrm{F}=\text { specific power of isotope in watt/gram. }
\end{aligned}
$$

The specific power of an isotope can be calculated from equation (1), or determined experimenta11y utilizing equation (4).

The calorimetrically determined wattage $(W)$ in equations (1) through (4) assumes that no significant amount of the energy of radioactive decay escapes undetected from the calorimeter and that the daughter isotope is stable.

In the case of parent-daughter decay in the sample,

$$
\begin{aligned}
& N_{1}=N_{0} e^{-\lambda_{1} t} \\
& N_{2}=\frac{\lambda_{2} N_{0}}{\lambda_{2}-\lambda_{1}}\left[e^{-\lambda_{1} t}-e^{-\lambda_{2}} t\right]
\end{aligned}
$$

where the subscripts 1 and 2 refer to the parent and daughter, respectively, and $\mathrm{N}_{0}=$ number of atoms of the parent at $t=0$. 
The wattage of the sample can then be calculated by adding the wattages of the parent and daughter obtained and by combining equation (2) with equations (5) and (6) as follows:

$$
\begin{aligned}
W_{a} & =W_{1}+W_{2} \\
& =1.60210 \times 10^{-3} \lambda_{1} N_{O} \quad\left[Q_{1} e^{-\lambda_{1} t}+\frac{Q_{2} \lambda_{2}}{\lambda_{2}-\lambda_{1}}\left(e^{-\lambda_{1} t}-e^{-\lambda_{2} t}\right)\right] .
\end{aligned}
$$

Alpha and beta radiation are completely absorbed by a calorimeter. Gamma radiation is much more penetrating, and the calorimeter must be constructed of sufficiently thick walls in order that only a small fraction of the energy may escape. The escaped energy $c$ an be calculated or measured with gamma detectors. From these results, corrections may be applied to the observed powers. However, for the materials involved in the reactor fuel cycle, no such corrections are necessary.

Reactor-grade plutonium consists of various amounts of the isotopes $238 \mathrm{Pu}, 239 \mathrm{Pu}, 240 \mathrm{Pu}, 241 \mathrm{Pu}, 242 \mathrm{Pu}$ and $241 \mathrm{Am}$, depending on the neutron spectrum of the reactor in which it was produced, the extent of fuel burnup, and the length of time from americium separation.

When a sample contains a mixture of isotopes, such as reactor fuels, the heat is merely the total of the individual constituents, which may be expressed as follows:

$$
W_{s}=\sum_{i=1}^{n} \quad W_{i}=\sum_{i=1}^{n} \quad m_{i} F_{i} \text {. }
$$

If the plutonium concentration and isotopic ratios of the material in a sample are known, the quantity of each isotope can be determined. Substituting $R_{i} m_{t o t}$ for $m_{i}$ (mass of a particular isotope) in equation (8) as follows:

$$
\mathrm{W}_{\mathrm{s}}=\mathrm{m}_{\mathrm{t}} \quad \sum_{\mathrm{i}=1}^{\mathrm{n}} \quad \mathrm{R}_{\mathrm{i}} \mathrm{F}_{1},
$$

where $\mathrm{m}_{\mathrm{t}}=$ the total weight of all isotopes (grams), and

$$
\mathrm{R}_{\mathrm{i}}=\text { the isotopic ratio of the } i^{\text {th }} \text { isotope. }
$$

The mass of a particular isotope can be obtained by rearranging equation (9) as follows:

$$
\mathrm{m}_{1}=\frac{\mathrm{R}_{1} \mathrm{~W}_{s}}{\mathrm{R}_{1} \mathrm{~F}_{1}+\mathrm{R}_{2} \mathrm{~F}_{2}+\cdot \cdot \mathrm{R}_{\mathrm{n}} \mathrm{F}_{\mathrm{n}}} .
$$


If the isotopic analysis and calorimetry date are within one month of each other, it is not necessary to compute the decay of the isotopic ratios. Normally, the uncertainties in the isotopic ratios will be larger than the amount of decay. However, when greater lengths of time are required (or to obtain better accuracy when large fractions of $24 \mathrm{Pu}$ are present), it is necessary that the isotopic ratios be decayed.

Generally, the precision of the calorimeter measurement is greater than the uncertainty associated with the mass spectrometric determination, which is no better than $0.3 \%$ for isotopes with concentrations greater than $10 \%$. For isotopes whose concentration 1 ies between 0.1 and $1 \%$, the minimum error is $1 \%$. Concentrations less than $0.1 \%$ may have errors from $5 \%$ to as much as $100 \%$ for concentrations in the range of $0.0010 \% .^{3}$ Therefore, it would be advantageous to compare the sample power at any time to the predicted value based on earlier calorimetric determinations.

There are two components of heat generation in which the specific power is greater than that of $239 \mathrm{Pu}$. These are $238 \mathrm{Pu}$ and $241 \mathrm{Am}$. The more serious of these is $238 \mathrm{Pu}$ for two reasons. First, it is the next lowest mass isotope to $239 \mathrm{Pu}$, and for this reason, errors in the isotopic determination due to spectrum "toe-tailing", (interference) from the major peak would tend to affect the already low abundance sensitivity of the minor $238 \mathrm{Pu}$ peak. Second, this potential error is compounded by the shorter alpha half-life of $238 \mathrm{Pu}$, which gives a specific power 250 times that of ${ }^{23^{9}} \mathrm{Pu}$.Although this is partially offset by the difference in the abundance ratios, it is not unusual for the component of heat generated by the decay of ${ }^{238} \mathrm{Pu}$ to almost equal that of the ${ }^{239} \mathrm{Pu}$. This effect is less pronounced in fast reactor plutonium than in light water reactor plutonium, due to the lower fraction of ${ }^{238} \mathrm{Pu}$ present in the sample. The other instance of an isotope with greater specific power than ${ }^{239} \mathrm{Pu}$ is americium. In this case, ${ }^{2} \mathrm{Am}$, which emits an alpha particle with a 432 yr half-life, is produced from the decay of $241 \mathrm{Pu}$. For this reason, a determination of the americium content of the sample is required, preferably at the time of mass spectrometric analysis. Because of the ingrowth of americium, the thermal output of reactor fuel samples will be observed to grow. The rate of this growth offers a method of verifying the ${ }^{24 I} \mathrm{Pu}$ content.

As an aid in the determination of the quantity of $238 \mathrm{Pu}$ and $241 \mathrm{Am}$ in the sample, it has been suggested that the neutrons, both spontaneous and those emitted from the $\alpha-n$ reaction, be measured simultaneously with the calorimetric determination. ${ }^{4}$ Also, gamma-ray spectroscopy could be used for an accurate and nondestructive determination of plutonium isotopic abundances. ${ }^{5,6}$ 


\section{THE DESIGN OF RADIONUCLIDE CALORIMETERS}

The subject of calorimetry is extensive and its techniques are usually involved and complicated.1 2 In general, a calorimeter is designed to accomplish a specific task or measurement. The concept of a "universal calorimeter" has never become a reality. The three main types of radionuclide calorimeters and their uses are as follows:

(1) Isotherma1 - temperature of the calorimeter remains constant during a reaction or calibration measurement. The heat output of the reaction or calibration measurement is determined by the time integrated heat exchange between calorimeter and its environment.

(2) Adiabatic - idea11y, no heat exchange between calorimeter and environment.

(3) Isotherma 1 Jacketed - the environment is temperature controlled, and the heat exchange between calorimeter and environment is a correction which must be applied to results.

As will be discussed later, the design of a calorimeter system may employ one or a combination of any or a 11 of the three main types described above.

Some of the factors which influence the design of a radionuclide calorimeter are listed as follows:

(1) The Sample - Norma11y, the amount of sample power, physical size and types of radiation determine the physical dimensions of the calorimeter. In general, large high wattage samples require "heavy" calorimeters, while low wattage samples require "light", highly sensitive microcalorimeters which are capable of measuring fractions of microwatts. Thus, the concept of a universal calorimeter is limited because a tradeoff must be made between larger sample sizes and higher calorimeter sensitivity. The thickness of the walls and the types of radiation involved will determine the fraction of heat which escapes from the calorimeter undetected. This fraction is normally quite low and can be accurately calculated so that it is only a minor consideration. 
(2) Calibration Method Used - Two methods are available for calibration: the first, use of a known radioactive sample or heat standard; the second, electrical heating or calibration. In both cases, the observed power of the sample is traceable to the primary electrical standards at the National Bureau of Standards.

(3) Time Per Assay - A complete assay involves both the sample run and calibration run. The time required to accomplish this is a complex function of al1 the following factors:

a. type of calorimeter - isotherma1, adiabatic or isothermal jacketed;

b. therma 1 conductivities and heat capacities of al1 the materials in the sample and calorimeter; and

c. construction techniques - precision machining is necessary to assure the uniform and constant thermal paths which are essential for reliable performance.

(4) The Leve1 of Accuracy Desired - Accuracy is dependent upon the following:
a. items outlined above under "Time Per Assay";
b. accuracy of the analysis of the relative abundance of isotopes present in the sample;
c. high precision in all measurements;
d. accuracy in correcting for the power not detected by the calorimeter.

In addition to the above design factors, consideration must be given to the environment in which the calorimeter will be used. For example, in-line or assay calorimeters are normally designed to be rugged, reliable and easy to operate while maintaining the specified accuracy.

Again, the concept of a specified calorimeter of a single design to cover all aspects of radionuclide calorimetry is not practical or economical when one considers all the factors which go into the design. Since 1949, many types of calorimeters have been used at this Laboratory. However, no other design has surpassed the precision, accuracy and ease of operation of the isothermal twin-type for radionuclide studies. 
Figure 1 shows a cut-away of an isothermal twin-bridge calorimeter. It consists of two identical thermels (thermal elements), each separated from the inner wall of a brass submarine jacket by an annular space. This "air gap" serves as a thermal resistance to heat produced in the sample area. Each thermel has a four terminal calibration heater bifilarly wound on an aluminum can which serves as the sample area. Plastic ends serve as supports for the sample area and reduce axial heat loss. Two nicke 1 resistance thermometers are wound over the entire length of each thermel, and the four windings are connected as a transposed-arm wheatstone bridge supplied with constant current (see Figure 2). The bridge potential (BP) is thus directly proportional to the temperature difference between the two sides of the calorimeter.

The calorimeter is operated in a constant temperature environmental bath. The twin design reduces the effect of environmental temperature fluctuations. For example, a temperature difference of a microdegree between the two sides can be measured even though the environmental bath is controlled to only a millidegree.

SAMPLE SIDE

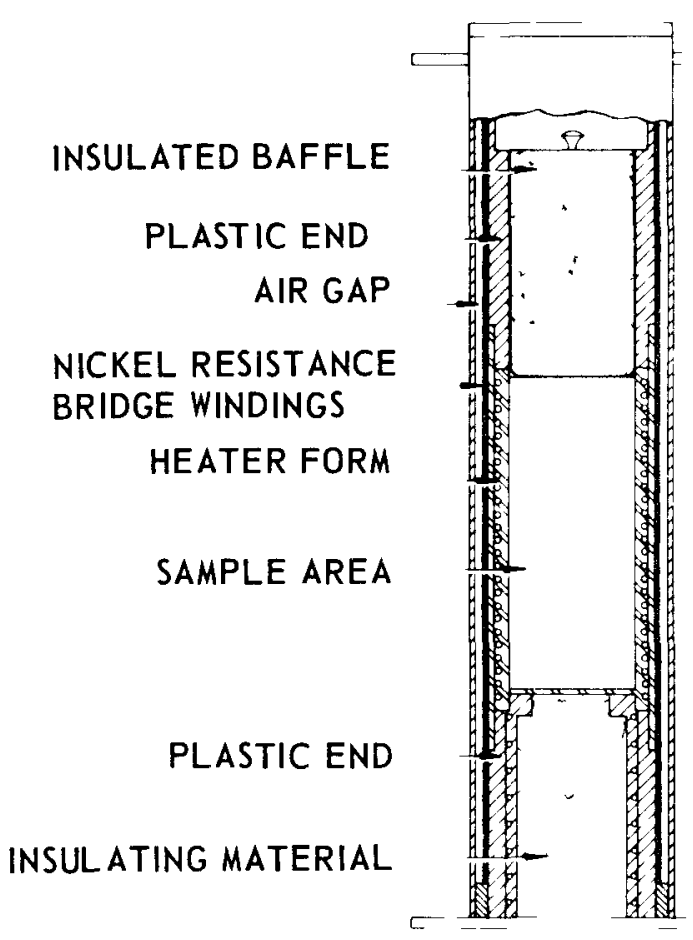

REFERENCE SIDE

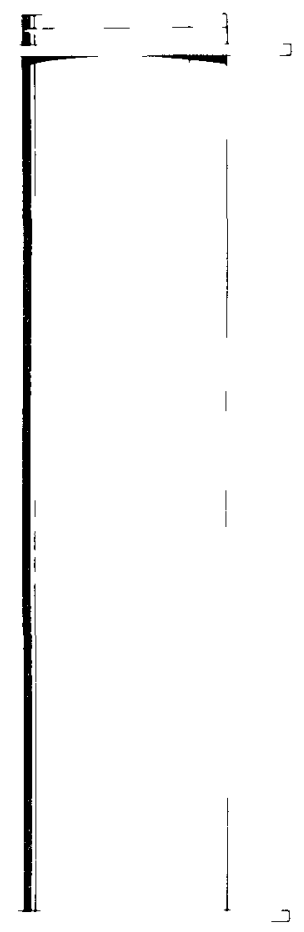

FIGURE 1 - Cross section of a typical isothermal twin-bridge calorimeter. 


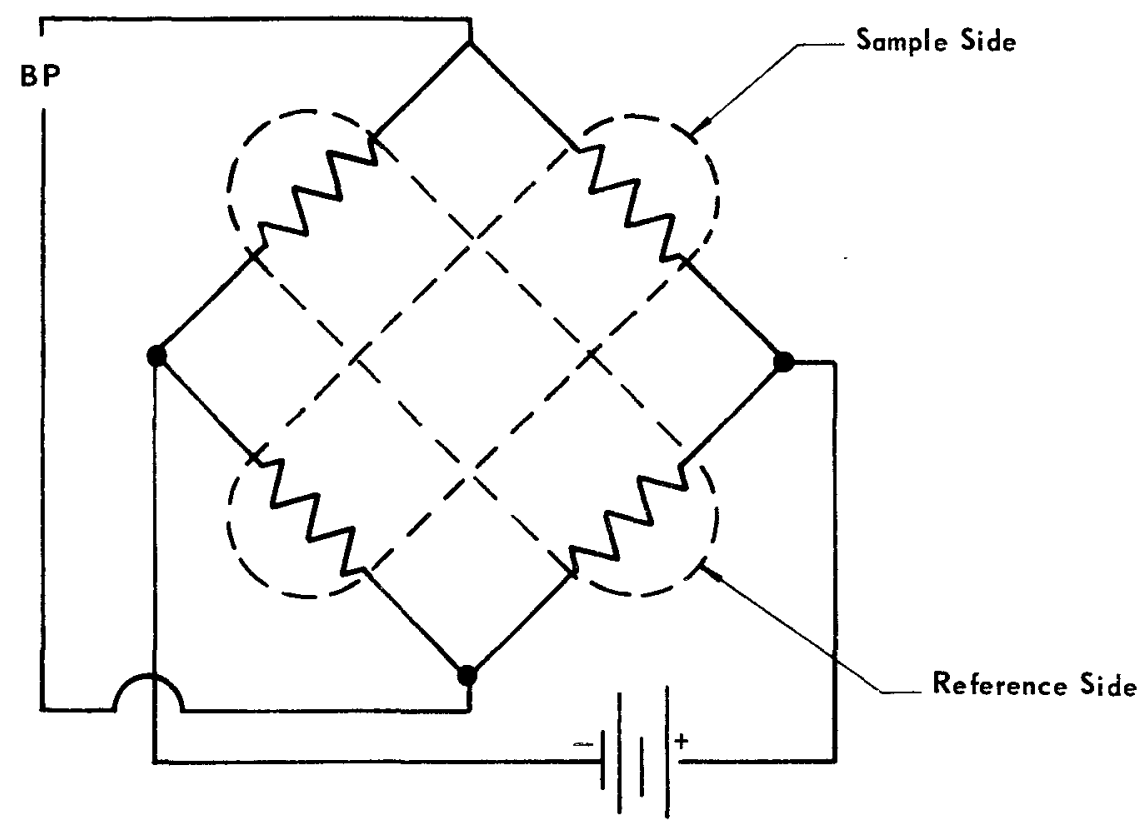

DIAGRAM OF BRIDGE CIRCUIT

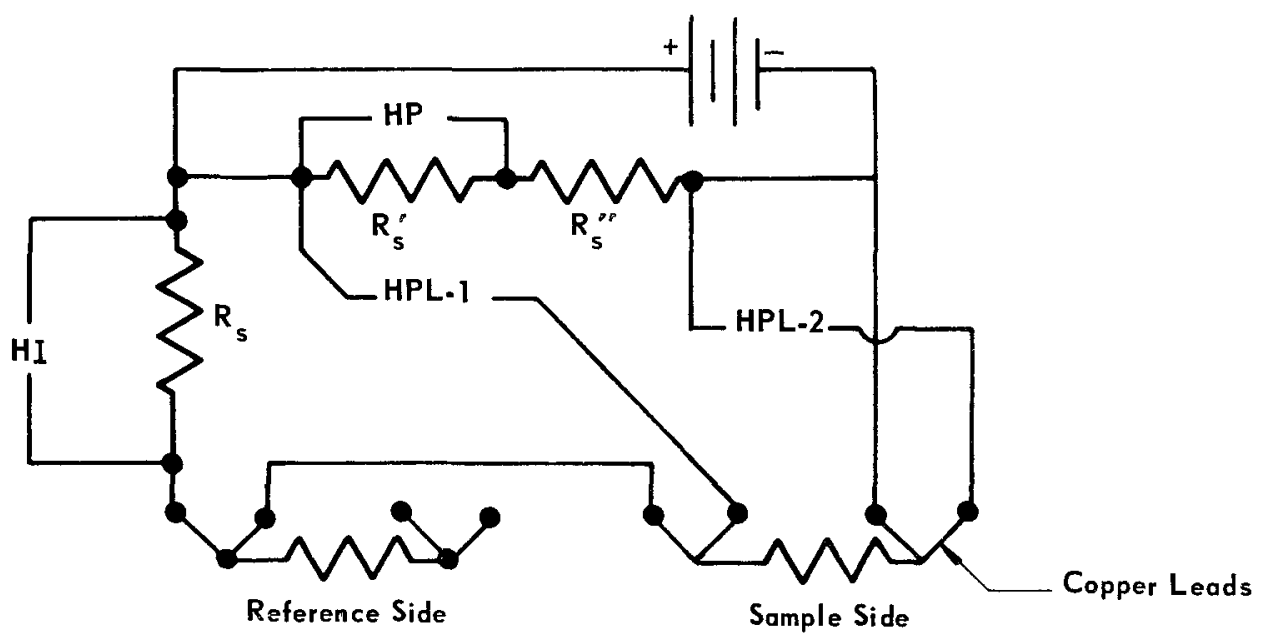

DIAGRAM OF HEATER CALIBRATION CIRCUIT

FIGURE 2 - Simplified sketches of the isothermal calorimeter circuitry. 
The construction of a precise heat flux calorimeter requires that (1) the thermal paths from the sample chamber to the environmental bath remain constant or reproducible; (2) the temperature of the environment remain constant; and (3) the temperature measured is representative of the sample (i.e., no matter where the sample is located in the sample chamber, top, bottom, or middle, the temperature rise observed is the same). The latter effect is often referred to as "heat distribution" error. The resistance thermometer may be considered as a heat flux averager. Assuming uniformity in the wire winding and the air gap, the resistance change of the section of the thermometer covering any surface is proportional to the temperature gradient, and hence, the heat flux through that element. Thus, the Mound-designed calorimeter has the effect of minimizing "heat distribution"errors.

With the calorimeter empty, a small bridge potential, BP。, may be observed. The $\mathrm{BP}_{\circ}$ is due to smal1 differences in the resistances of each arm and small variations in the thickness of the air gap.

When a radioactive sample is placed into the sample chamber, the temperature rises inside the sample chamber until the heat losses through the nickel thermometer and across the air gap to the jacket and environmental bath equals the heat being generated by the sample. When this steadystate condition exists, the temperature rise, observed by reading the potential across the wheatstone bridge is proportional to the amount of heat being generated. Axial heat losses through the plastic ends and insulating materials are considered negligible or reproducible during calibration of the calorimeters.

The time required to reach this steady-state condition is proportional to the heat capacity of the sample and sample chamber, and the therma 1 conductivities of the materials between the sample and the environmental bath (this includes the air-gap, thermel form and the packaging of the sample). Inasmuch as the calorimeter is fabricated to have constant or reproducible thermal paths, the packaging of the sample in most cases is the factor which controls the required time to reach steady-state temperature equilibrium.

After the sample has reached equilibrium and the bridge potential, $\mathrm{BP}_{3}$, is read using a potentiometer (or high input impedence digital voltmeter), the sample is removed from the calorimeter and the calorimeter is calibrated electrically. A highly regulated dc power supply is used to supply power to the four terminal calibration heaters built into the calorimeter. Figure 2 shows a wiring schematic of the heater calibration circuit. The heaters are fabricated from low temperature coefficient wire such as manganin with copper heater leads. 
The heater lead problem (i.e., power generated in leads) normally inherent in single sided calorimeter design is minimized in the twin calorimeter. This is accomplished by utilizing a heater circuit with identical leads to heaters in both the sample and reference sides. When the heater on the sample side is used, current passes through two leads on the sample side and two leads on the reference side of the calorimeter. Thus, the differential calorimeter design compensates for the heat in the leads since both sides have identical power in leads (see Figure 2).

The power dissipated in the heater is expressed by

$$
\mathrm{W}_{\mathrm{h}}=\mathrm{EI},
$$

where

$$
\begin{aligned}
& \mathrm{W}_{\mathrm{h}}=\text { watts in heater } \\
& \mathrm{E}=\text { voltage across heater } \\
& \mathrm{I}=\text { current in amperes through heater. }
\end{aligned}
$$

The current through the heater is determined by measuring the voltage across a standard resistor:

$$
I=\frac{H I}{R_{s}}
$$

where $I=$ current in amperes through standard resistor

$$
\begin{aligned}
& \mathrm{HI}=\text { voltage across the standard resistor (Figure 2) } \\
& \mathrm{R}_{s}=\text { value of standard resistor in ohms. }
\end{aligned}
$$

The voltage across the heater is determined indirectly by using a voltage divider and subtracting the voltage drops in the heater leads (HPL1 and HPL2). The following equation applies:

$$
E=\left(\frac{R_{s}^{\prime}+R_{s}^{\prime}}{R_{s}^{\prime}}\right) H P-H P L_{1}-H P L_{2}
$$

where

$$
\mathrm{E}=\text { voltage across the heater }
$$

$\frac{R_{s}^{\prime}+R_{s}^{\prime \prime}}{R_{s}^{\prime}}=$ ratio of voltage divider 


$$
\begin{aligned}
& \mathrm{HP} \quad=\text { voltage across resistor } \mathrm{R}_{s}^{\prime} \\
& \mathrm{HPL}_{1}=\text { voltage drop in lead one (see Figure 2) } \\
& \mathrm{HPL}_{2}=\text { voltage drop in lead two (see Figure 2) }
\end{aligned}
$$

thus

$$
W_{h}=\left[\left(\frac{R_{s}^{\prime}+R_{s}^{\prime \prime}}{R_{s}^{\prime}}\right) H P-H P L_{1}-H P L_{2}\right] \frac{H I}{R_{s}}
$$

When steady-state temperature equilibrium is reached with electrical heating, the bridge potential $\mathrm{BP}_{\mathrm{h}}$, is measured.

The electrical calibration is carried out to duplicate the thermal output of the sample. The following equation is used to calculate sample power:

where

$$
W_{s}=W_{h}+\frac{B P_{s}-B P_{h}}{S}
$$

$$
\begin{aligned}
& \mathrm{W}_{\mathrm{s}}=\text { watts in sample } \\
& \mathrm{W}_{\mathrm{h}}=\text { watts in heater } \\
& \mathrm{BP}_{\mathrm{s}}=\text { bridge potential with sample }(\mu \mathrm{V}) \\
& \mathrm{BP}_{\mathrm{h}}=\text { bridge potential with heater }(\mu \mathrm{V}) \\
& \mathrm{S} \quad=\text { sensitivity of the calorimeter }(\mu \mathrm{V} / \text { watt })
\end{aligned}
$$

The sensitivity is essentially constant over increments of 0.1 to 0.2 watts and thus exact duplication of power is not necessary providing power levels are within $5 \%$. The sensitivity of the calorimeter, $S$, is determined using electrical calibration or standardized radioisotopic heat sources. The following equation is used to determine the calorimeter sensitivity and may be checked at each electrical calibration of the calorimeter:

$$
S=\frac{B P_{h}-B P_{\circ}}{W_{h}} .
$$

The foregoing description of operating the calorimeter is called the Replacement Method. In general terms, the sample power is replaced with electrical power. There are two other methods of operating the calorimeter; the Differential Method, and the Isothermal Method." 
In the Differential Method, electrical heat in the reference side of the calorimeter is compared directly to the sample heat. This method allows determinations in about half the time required for the "replacement method" since the sample and heater run are effectively made simultaneously. However, operation in this mode requires a foreknowledge of the sample to within about $1 \%$ and is normally most useful when many samples of approximately the same size are measured. For unknown samples, this method is only slightly faster than the replacement method. When using this method, the sample power is calculated from the following equation:

$$
W_{s}=W_{h}+\frac{B P_{s}-B P_{m}}{S}
$$

where the slope correction $\left(\mathrm{BP}_{\mathrm{m}}\right)$ is equal to the slope factor (m) times the watts in the heater $\left(W_{n}\right)$, or

$$
\mathrm{BP}_{\mathrm{w}}=\mathrm{mW}_{\mathrm{h}}
$$

In the Differential Method the quantity $\mathrm{BP}_{6}-\mathrm{BP}_{\mathrm{m}}$ will be zero if the power in the reference side exactly matches the sample power.

The quantity $\mathrm{BP}_{\mathrm{m}}$ compensates for small differences in the two sides of the calorimeter and is determined by running current through the sample and reference heaters connected electrically in series. The resulting bridge off-balance is then plotted versus the power in the sample side which generally results in a straight line.

The other mode of operation, which is sometimes used to speed up the time per assay, is the Isothermal Method. In this method, the temperature of the calorimeter is maintained several degrees above the temperature of the bath by a servo-controller (see Figure 3). This is accomplished by shunting one arm of the bridge such that it is at balance when there is $W_{0}$ watts of power on the sample side of the calorimeter. The amount of power supplied to the empty calorimeter, $W_{0}$, is measured by means of a current squared to voltage transducer placed in series with the calorimeter heater. This device averages the fluctuations of the servo-controller output and supplies a dc voltage proportional to the heat input to the calorimeter. When a sample is placed in the calorimeter, the control power drops to a lower level, $W_{0}^{\prime}$. The power of the sample is merely the difference between the two readings, or

$$
W_{s}=W_{0}-W_{0}^{\prime} \cdot
$$

No correction is needed here since the temperature, and hence the power input, is kept constant by means of the controller. The isothermal method eliminates the time constant of the calorimeter entirely so that the time to reach equilibrium depends only on the time constant of the sample itself. This time limitation can be reduced still further by preequilibrating the sample in a "thermalizing well" in the same environmental water bath (see Figure 4). 


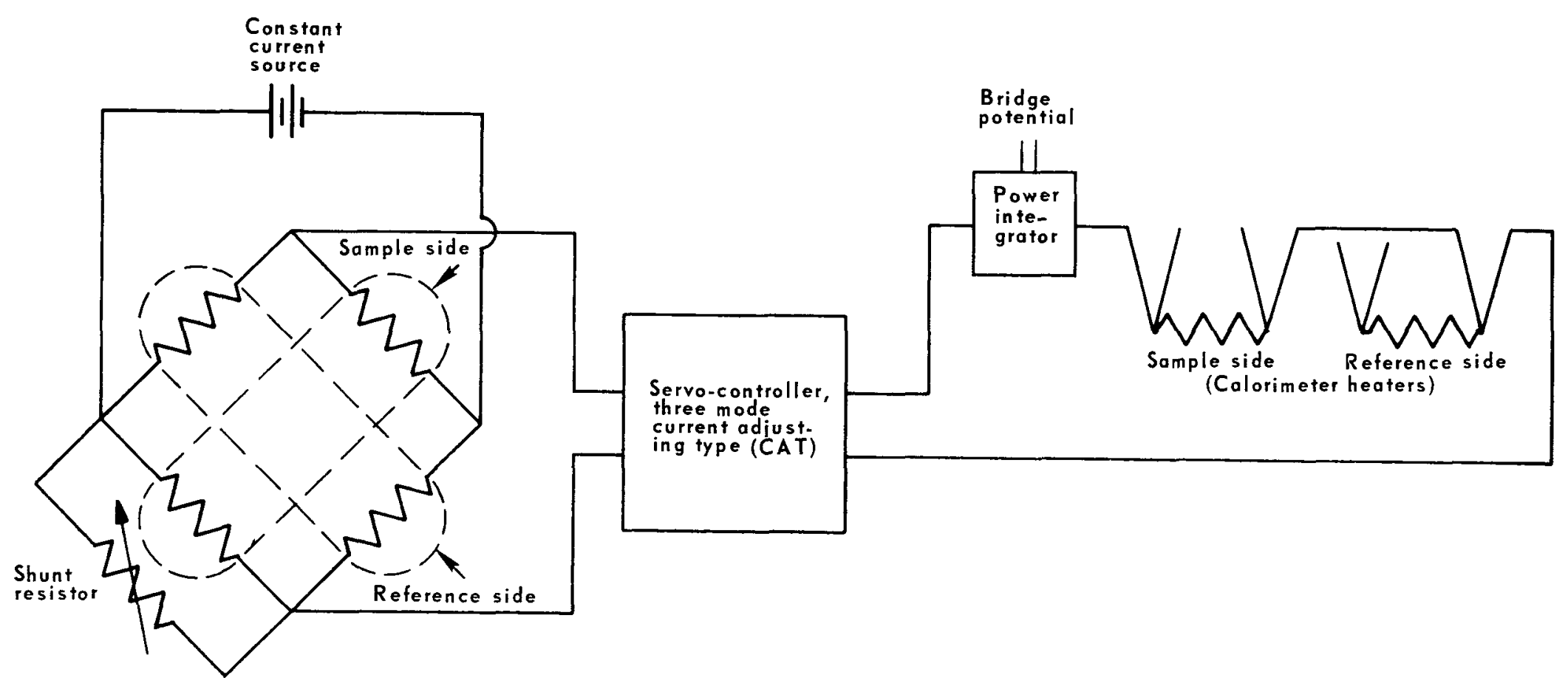

FIGURE 3 - Circuitry arrangement for the Isothermal Method of operation. 
The effect of packaging, automatic servo-control, pre-equilibration and desired accuracy on the equilibrium time has been investigated.

When a calorimeter is automated, the temperature of the sample chamber is held constant. Since the overriding constraint on thermal equilibrium of the sample is packaging, pre-equilibrating the sample to the calorimeter temperature, can greatly reduce the equilibrium time in the calorimeter.* In this case, the only thermal disturbance which must be undergone will occur during transfer of the sample from the thermalizing well to the calorimeter.

In an attempt to illustrate some of the trade-offs in time and accuracy, a series of experiments were performed in order to incorporate the factors mentioned above. These included the following cases:

1. Unautomated calorimeter and empty sample adaptor can;

2. Unautomated calorimeter, sample in adaptor can spaced with plastic bags and shot;

3. Automated calorimeter, sample in adaptor can;

4. Automated calorimeter, sample can previously in thermalizing well controlled to within $0.007^{\circ} \mathrm{C}$ of calorimeter chamber;

5. Idea1 case: sample at equilibrium, removed and reinserted;

6. Case 2 (above), with copper shot between sample and adaptor.

The results of these experiments are shown in Table 1 . It can be seen that if less precise results can be tolerated, the necessary equilibrium time can be significantly reduced. Also, faster equilibrium times may be achieved with the addition of automatic temperature controllers and equilibration tubes.

*This is especially useful when a calorimeter is automated and the temperature of the sample chamber is held constant. 
Table 1

TIME TO REACH DESIRED EQUILIBRIUM

\begin{tabular}{|c|c|c|c|c|}
\hline Case & $\begin{array}{c}0.01 \% \\
\text { Equilibrium }\end{array}$ & $\begin{array}{c}\frac{\text { Time }(h r)}{0.1 \%} \\
\text { Equilibrium }\end{array}$ & $\begin{array}{c}1.0 \% \\
\text { Equilibrium }\end{array}$ & Comments \\
\hline 1 & 4.8 & 3.6 & 2.8 & $\begin{array}{l}\text { Heater only, no } \\
\text { sample }\end{array}$ \\
\hline 2 & 13.1 & 10.2 & 8.1 & $\begin{array}{l}\text { Poorly packaged } \\
\text { sample in unauto- } \\
\text { mated calorimeter }\end{array}$ \\
\hline 3 & 8.0 & 6.1 & 4.7 & $\begin{array}{l}\text { Same as Case } 2 \text { with } \\
\text { calorimeter automated }\end{array}$ \\
\hline 4 & 3.0 & 1.6 & 0.8 & $\begin{array}{l}\text { Same as Case } 3 \text { with } \\
\text { sample pre-equili- } \\
\text { brated within } 0.007^{\circ} \mathrm{C}\end{array}$ \\
\hline 5 & 3.0 & 1.3 & 0.4 & $\begin{array}{l}\text { Ideal case; sample } \\
\text { at exact calorimeter } \\
\text { temperature }\end{array}$ \\
\hline 6 & 8.0 & 6.3 & 5.2 & $\begin{array}{l}\text { Same as Case } 2 \text { with } \\
\text { improved packaging }\end{array}$ \\
\hline
\end{tabular}

The calorimeter system (shown in Figure 4) includes a calorimeter, a regulated power supply, an environmental bath, a control pane1, and a readout device (potentiometer or digital voltmeter). The control pane1 selects heater circuitry and contains the standard resistor for measuring current through the heater as well as a voltage divider network to measure the voltage drop across the heater. Additional equipment may include a recorder, a servo-controller and integrator (for isothermal operation), a master control panel for selection when several calorimeters are being operated and a calculator. Figure 4 also shows a typical console for operating two calorimeters in the isothermal mode. The calorimeter and environmental bath may be located adjacent to the console or as much as $100 \mathrm{ft}$ away in a different area. Figure 5 shows an arrangement of several calorimeters located at various distances from the master control console for an actual installation. 


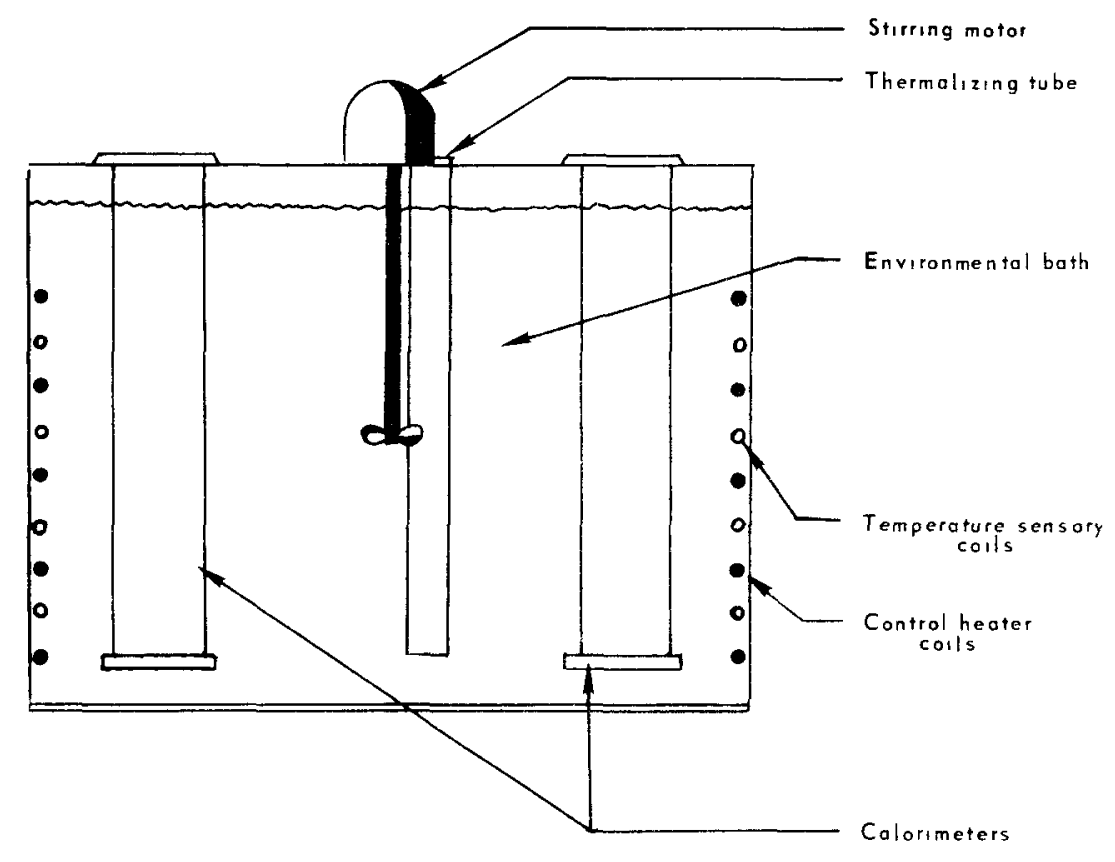

ENVIRONMENTAL BATH

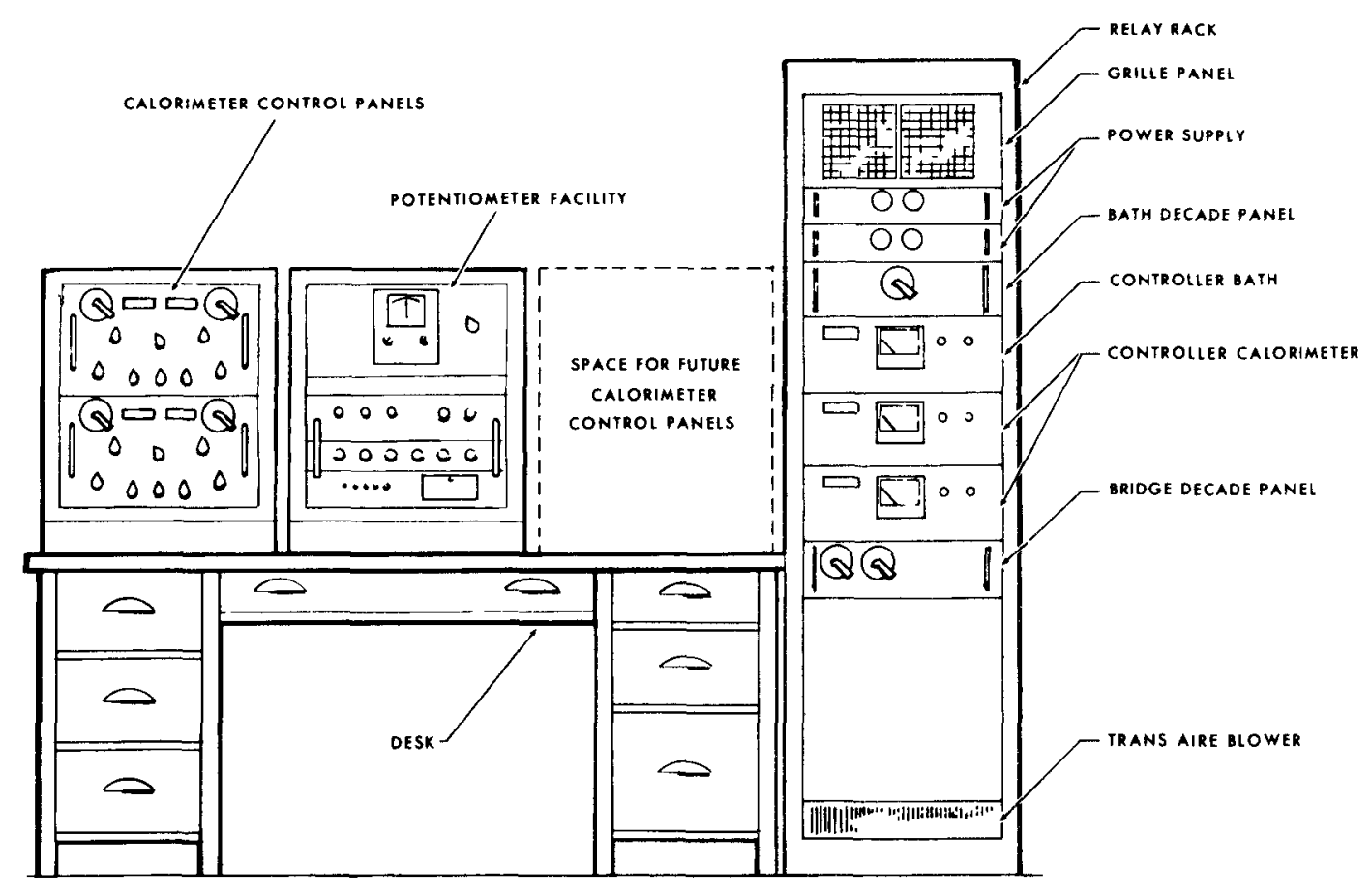

CONSOLE ARRANGEMENT

FIGURE 4 - Components used in a typical isothermal calorimeter system. 


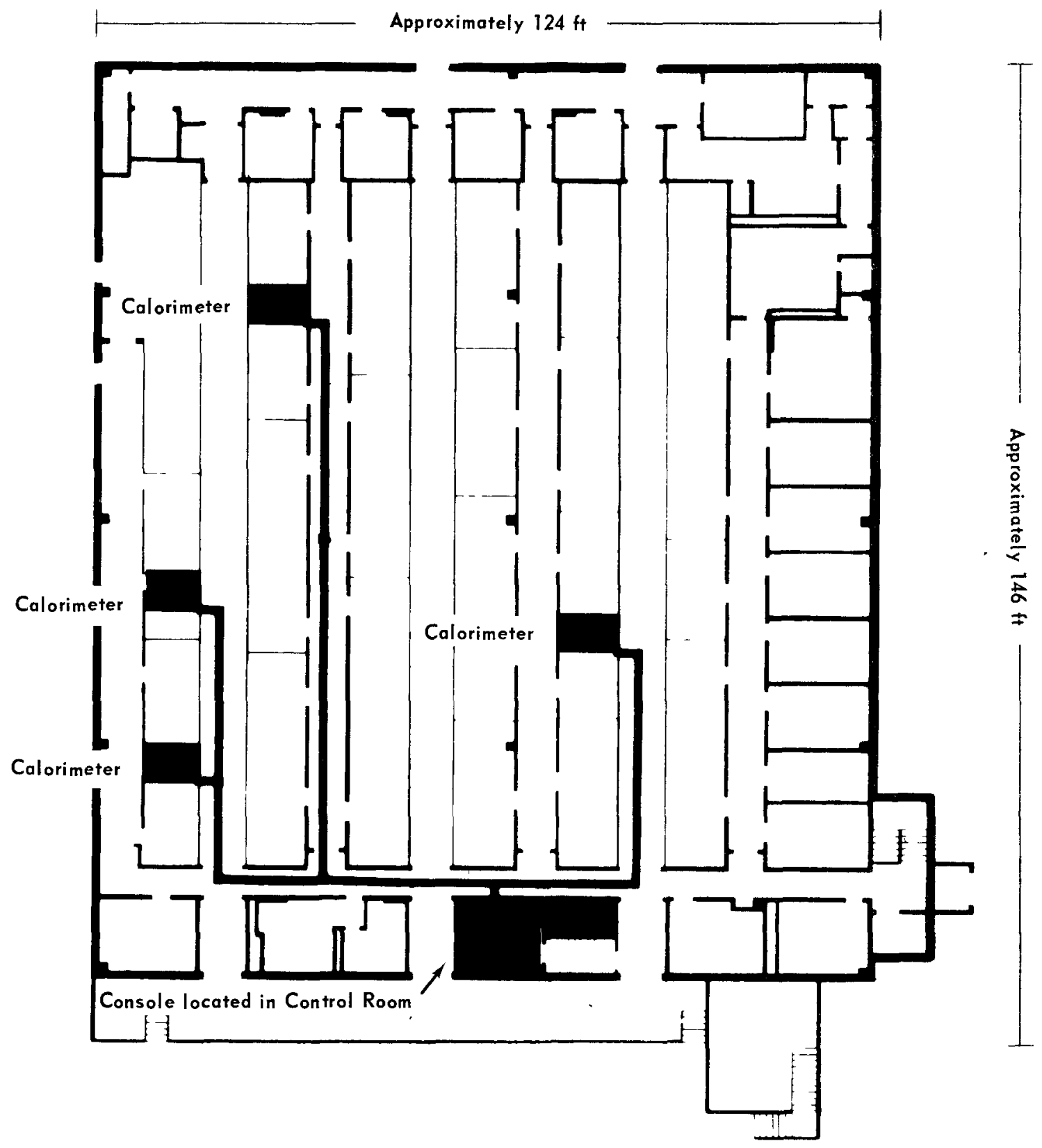

FIGURE 5 - Calorimeter installations in Mound Laboratory's plutonium processing building. 


\section{EXPERIMENTAL}

The loan of the two samples from Atlantic Richfield Hanford Company (ARHCO) was arranged by the AEC/Office of Safeguards and Materials Management (OSMM) through the Richland Operations Office. The isotopic composition of the samples used were characteristic of feed material produced in 1 ight water reactors and fast breeder reactors.

The oxide was packaged in a sealed "tuna fish can", two sealed plastic bags and an outer can with Drierite between the bags and outer can. Details on the composition of these samples are given in Table 2 . The only assay requested other than that. normally provided was an americium analysis.

A series of measurements were made over a time span of 48 days to approximate the time scale of a typical shipper-receiver exchange.

Table 2

SAMPLE DESCRIPTION

\begin{tabular}{|c|c|c|}
\hline & $\begin{array}{r}\text { Light Water } \\
\text { Reactor Sample } \\
\end{array}$ & $\begin{array}{l}\text { Fast Reactor } \\
\text { Feed Sample } \\
\end{array}$ \\
\hline Sample Designation & $\mathrm{RL}-101-0-30-3-2$ & RL-101-0-30-3-3 \\
\hline Net oxide weight (g) & $1,037.8$ & $1,136.0$ \\
\hline $\mathrm{Pu}$ content $(\%)^{\mathrm{a}}$ & 86.36 & 87.17 \\
\hline $\mathrm{Pu}$ content $(\mathrm{g})$ & 896.24 & 990.3 \\
\hline \multicolumn{3}{|l|}{ Isotopic analysis ${ }^{a}$ (wt \%) } \\
\hline $238 \mathrm{Pu}$ & 0.236 & 0.058 \\
\hline a $39 \mathrm{Pu}$ & 75.647 & 85.676 \\
\hline $24{ }^{\circ} \mathrm{Pu}$ & 18.424 & 12.111 \\
\hline $241 \mathrm{Pu}$ & 4.585 & 1.940 \\
\hline $\mathbf{a}_{4}{ }^{2} \mathrm{Pu}$ & 1.108 & 0.215 \\
\hline \multicolumn{3}{|l|}{ Am concentration ${ }^{b}(\mathrm{ppm})$} \\
\hline (assumed to be ${ }^{241} \mathrm{Am}$ ) & 6,334 & 1,376 \\
\hline \multicolumn{3}{|l|}{ Total metal1ic } \\
\hline impurities $^{a}$ (ppm) & 1,220 & 952 \\
\hline
\end{tabular}


The calorimeter used in this investigation was Mound Laboratory Mode1 102 , Serial No. 104, which is of the isothermal twin bridge type described earlier. The sample chamber is $4.75 \mathrm{in.}(12.07 \mathrm{~cm})$ in diameter by 8.75 in. $(22.23 \mathrm{~cm})$ long. An aluminum calorimeter sample can, which fits snugly into the sample chamber, was used to load samples into the calorimeter. The wall and bottom thickness of this sample can are approximately $0.25 \mathrm{in} .(0.64 \mathrm{~cm})$ and reduce the usable volume of the sample cavity to 4.25 in. $(10.80 \mathrm{~cm})$ diameter by 8.5 in. $(21.59 \mathrm{~cm})$ long. The calorimeter was operated using the replacement method described above.

Both the precision and accuracy of the calorimeter were determined by using a Mound Laboratory two-watt standard heat source, the power of which was known accurately to $\pm 0.007 \%$. On a series of twelve measurements the standard deviation from the known value was $\pm 0.02 \%$ with an average bias of less than $0.01 \%$. Thus, at the $95 \%$ confidence level, the accuracy of the calorimeter was slightly better than $\pm 0.05 \%$.

An oxide sample was placed in the calorimeter sample can and the void space between the can and the packaged sample was filled with copper shot to assure good thermal contact between cans. The sample was loaded into the calorimeter and allowed to come to steady-state equilibrium. The time required to reach equilibrium was approximately six hours. A recording system was used which allows the operator to suppress all but a small fraction of the dc output from the calorimeter bridge and record this small fraction to have a visual trace of the equilibrium conditions (both empty and loaded) of the calorimeter (see Figure 6). After equilibrium was attained, the bridge potential was measured using a Guildiine 9160-G potentiometer and a Leeds and Northrup 9834 nul1 detector. The sample was removed and replaced with an empty oxide container. The calorimeter was then calibrated electrically by the replacement method which has been described in the Background section of this report.

Typically, one sample determination per day was run with a total operator time of one hour including calculations.

The calculation of the plutonium content from both the wattage and the isotopic data was performed by utilization of Mound Laboratory's "Plutonium Isotope Accountability Program (S025)". This is an IBM 360-50 compatible program which takes as input the isotopic ratios, specific powers, the time from americium separation to mass spectral determination (which can be determined from the ratio of ${ }^{241} \mathrm{Pu}$ to ${ }^{341} \mathrm{Am}$ found by chemical analysis), and the time from mass spectrometric analysis to calorimetric determinations. The total quantity of plutonium in grams at the date of the mass spectra 1 analysis, the grams of each plutonium isotope, the power of each isotope on the date of the calorimetric analysis, and the total sample power by day for any period of time desired are calculated and printed out. The decay constants used in this program are given in Table 3 , and an example of a manual calculation of each sample is given in the appendix. 

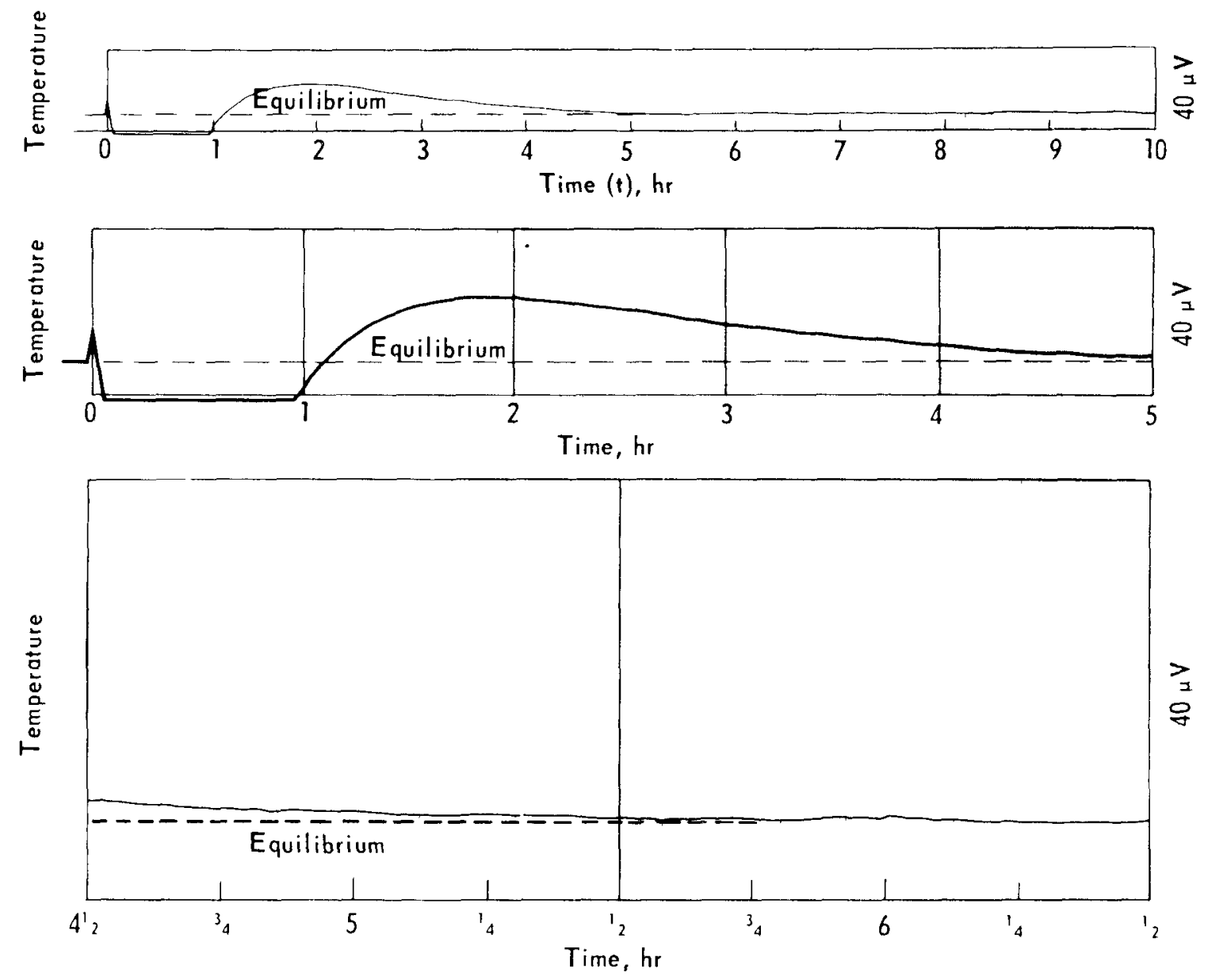

Figure 6: Approach to Equilibrium for Feed Material Sample 
Table 3

NUCLEAR CONSTANTS FOR ISOTOPES IN PLUTONIUM FUEL

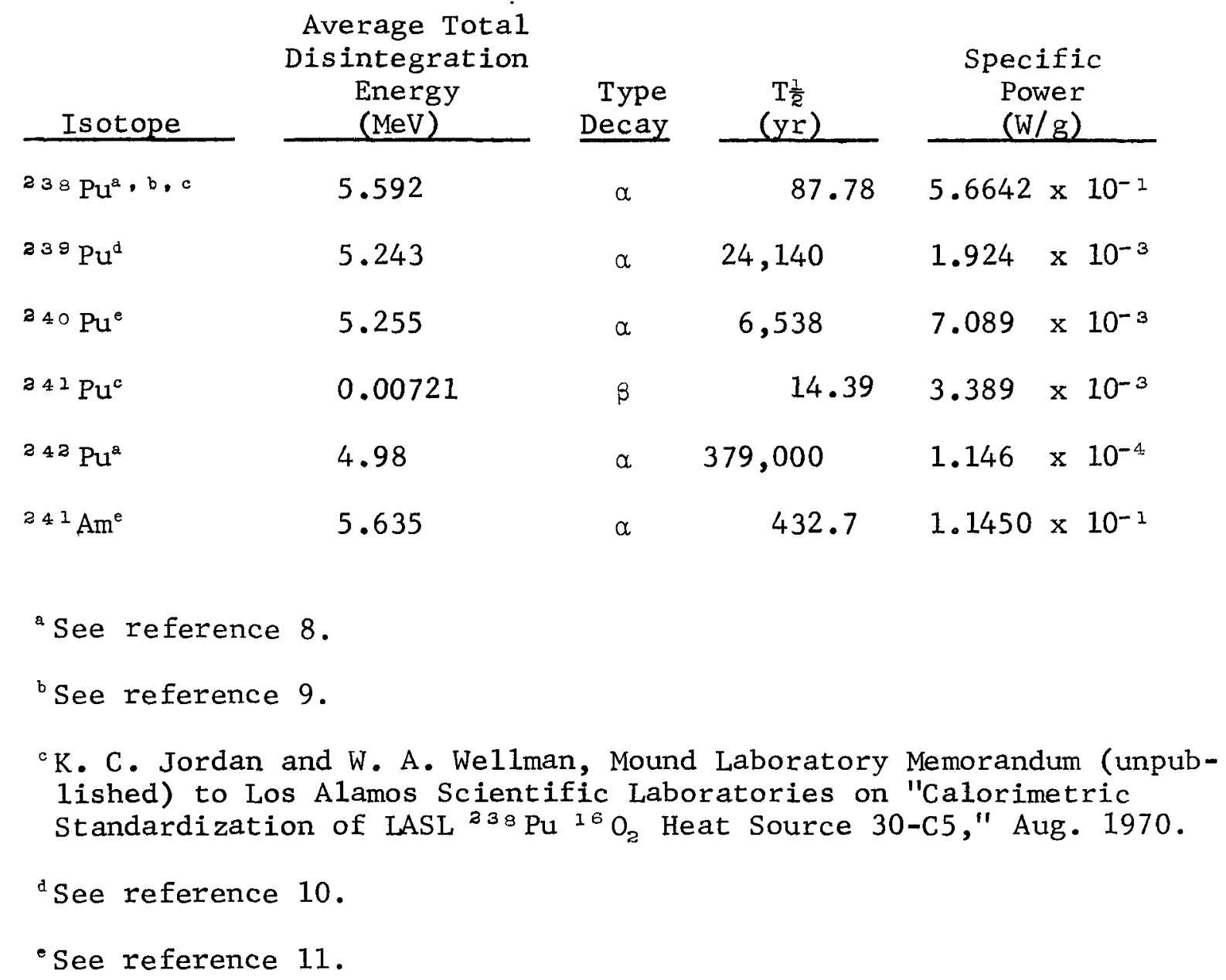

Average Total

isintegration Energy

Decay

Power

5.592

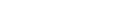

$.6642 \times 10^{-1}$ 


\section{RESULTS}

A total of 27 runs were made on the two samples and the results are shown in Tables 4 and 5. Graphs of these results (see Figures 7 and 8 ) demonstrate the following two points: first, the precision of the measurements on the unknown was well within that determined on the standard heat source used to check the instrument $\left(2_{\sigma}=0.03 \%\right.$ versus $\left.0.05 \%\right)$. Thus, the unknowns were as easy to reproduce as the known. The second point is the rate of growth of the power due to ${ }^{241} \mathrm{Pu}$. When calorimetry is used as a comparison for shipper-receiver reports, tampering with the sample would be an extremely difficult task and could be detected by comparing both the total power and the rate of growth of the sample power (see Table 6). For example, in 8 days the power of the LWR sample grows $0.1 \%$ and for the FRF sample this change takes 11 days. 
Table 4

LIGHT WATER REACTOR SAMPLE

\begin{tabular}{|c|c|c|c|c|c|}
\hline Run & $\underline{\text { Day }}$ & Date & $\begin{array}{c}\text { Calorimeter } \\
\text { Value } \\
(W) \\
\end{array}$ & $\begin{array}{c}\text { Amount of } \mathrm{Pu} \\
\text { at time of } \\
\text { Mass Spectrometry } \\
(\mathrm{g})\end{array}$ & $\begin{array}{c}\text { Deviation } \\
(\mathrm{g}) \\
\end{array}$ \\
\hline I & 1587 & $5 / 07 / 70$ & 4.64799 & 905.80 & -0.12 \\
\hline II & 1588 & $5 / 08 / 70$ & 4.64973 & 906.03 & +0.11 \\
\hline III & 1591 & $5 / 11 / 70$ & 4.64973 & 905.70 & -0.23 \\
\hline IV & 1592 & $5 / 12 / 70$ & 4.65160 & 905.95 & +0.03 \\
\hline $\mathrm{V}$ & 1593 & $5 / 13 / 70$ & 4.65294 & 906.10 & +0.18 \\
\hline VI & 1594 & $5 / 14 / 70$ & 4.65266 & 905.94 & +0.02 \\
\hline VII & 1595 & $5 / 15 / 70$ & 4.65305 & 905.90 & -0.02 \\
\hline VIII & 1627 & $6 / 16 / 70$ & 4.67109 & 905.88 & -0.04 \\
\hline IX & 1628 & $6 / 17 / 70$ & 4.67159 & 905.86 & -0.06 \\
\hline $\mathrm{X}$ & 1629 & $6 / 18 / 70$ & 4.67276 & 905.98 & +0.06 \\
\hline$X I$ & 1630 & $6 / 19 / 70$ & 4.67389 & 906.09 & +0.17 \\
\hline XII & 1633 & $6 / 22 / 70$ & 4.67466 & 905.94 & -0.01 \\
\hline XIII & 1634 & $6 / 23 / 70$ & 4.67471 & 905.81 & -0.11 \\
\hline
\end{tabular}

Mean 905.95

Average (for day 1611) $=3.05944$

905.98

$$
\begin{aligned}
\sigma=\sqrt{\frac{\sum \mathrm{D}^{2}}{\mathrm{n}-1}} & =0.12 \mathrm{~g} \\
2 \sigma & =0.23 \mathrm{~g}=0.025 \%
\end{aligned}
$$


Table 5

FAST REACTOR FEED

\begin{tabular}{|c|c|c|c|c|c|}
\hline$\underline{\text { Run }}$ & $\underline{\text { Day }}$ & Date & $\begin{array}{c}\text { Calorimeter } \\
\text { Value } \\
(W) \\
\end{array}$ & $\begin{array}{c}\text { Amount of } \mathrm{Pu} \\
\text { at time of } \\
\text { Mass Spectrometry } \\
(\mathrm{g})\end{array}$ & $\begin{array}{c}\text { Deviation } \\
\text { (g) }\end{array}$ \\
\hline I & 1598 & $5 / 18 / 70$ & 3.05552 & 985.15 & -0.14 \\
\hline II & 1599 & $5 / 19 / 70$ & 3.05643 & 985.36 & +0.07 \\
\hline III & 1600 & $5 / 20 / 70$ & 3.05631 & 985.24 & -0.05 \\
\hline IV & 1601 & $5 / 21 / 70$ & 3.05709 & 985.40 & +0.11 \\
\hline V & 1602 & $5 / 22 / 70$ & 3.05717 & 985.34 & +0.05 \\
\hline VI & 1605 & $5 / 25 / 70$ & 3.05739 & 985.16 & -0.13 \\
\hline VII & 1606 & $5 / 26 / 70$ & 3.05797 & 985.26 & -0.03 \\
\hline VIII & 1607 & $5 / 27 / 70$ & 3.05826 & 985.27 & -0.02 \\
\hline IX & 1612 & $6 / 01 / 70$ & 3.05964 & 985.29 & 0.00 \\
\hline $\mathrm{x}$ & 1616 & $6 / 05 / 70$ & 3.06082 & 985.33 & +0.04 \\
\hline $\mathrm{XI}$ & 1619 & $6 / 08 / 70$ & 3.06095 & 985.12 & -0.17 \\
\hline $\mathrm{XII}$ & 1621 & $6 / 10 / 70$ & 3.06235 & 985.40 & +0.11 \\
\hline XIII & 1635 & $6 / 24 / 70$ & 3.06649 & 985.55 & +0.26 \\
\hline XIV & 1636 & $6 / 25 / 70$ & 3.06573 & 985.22 & -0.07 \\
\hline
\end{tabular}

Mean 985.29

Average (for day 1609) $=4.66126$

985.31

$$
\begin{aligned}
\tau=\frac{\sqrt{\sqrt{\mathrm{D}^{2}}}}{\mathrm{n}-1} & =0.12 \mathrm{~g} \\
2 \sigma & =0.23 \mathrm{~g}=0.024 \%
\end{aligned}
$$




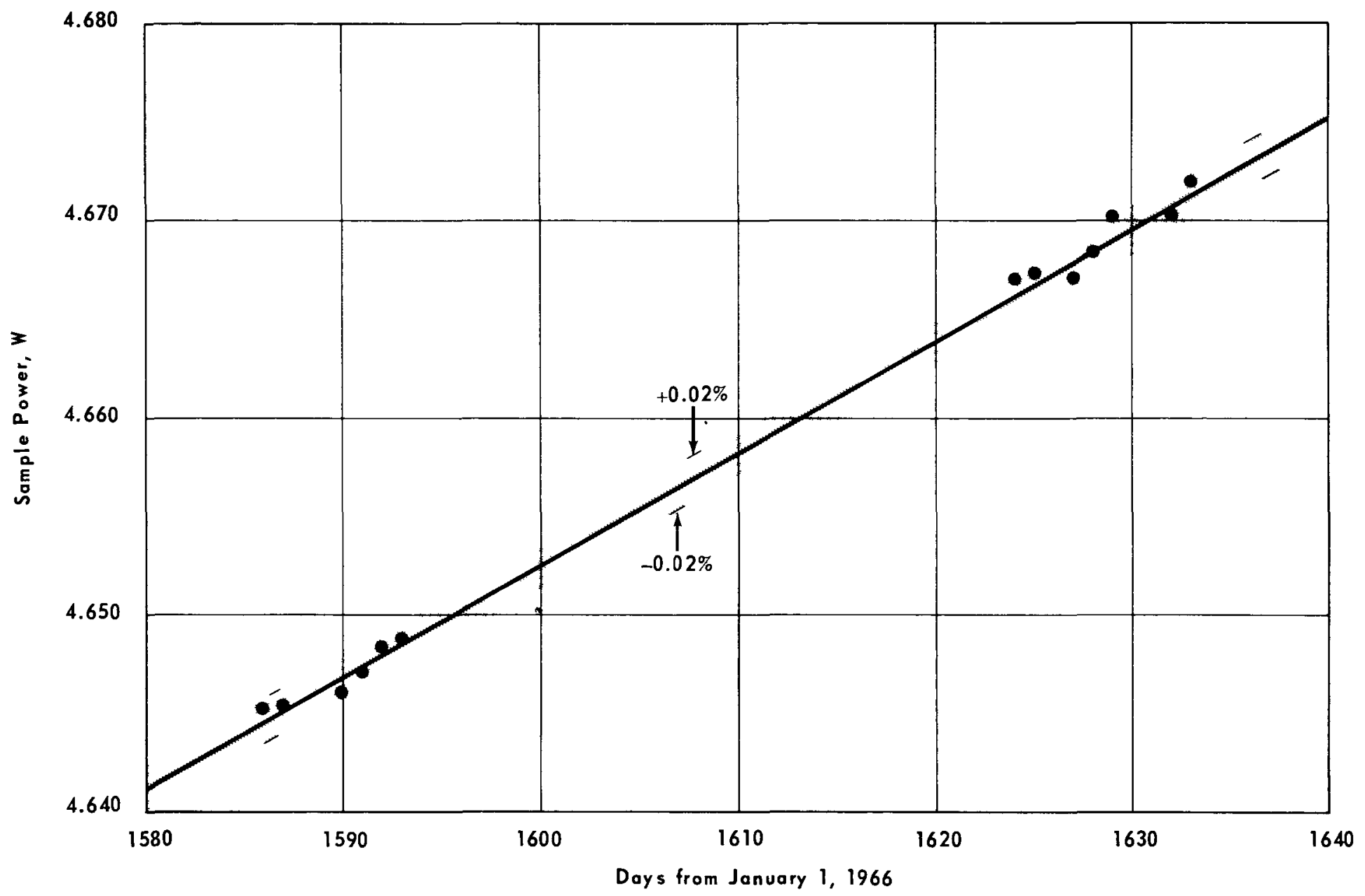

Figure 7 - Decay values for the LWR sample (also, see Table 3). 


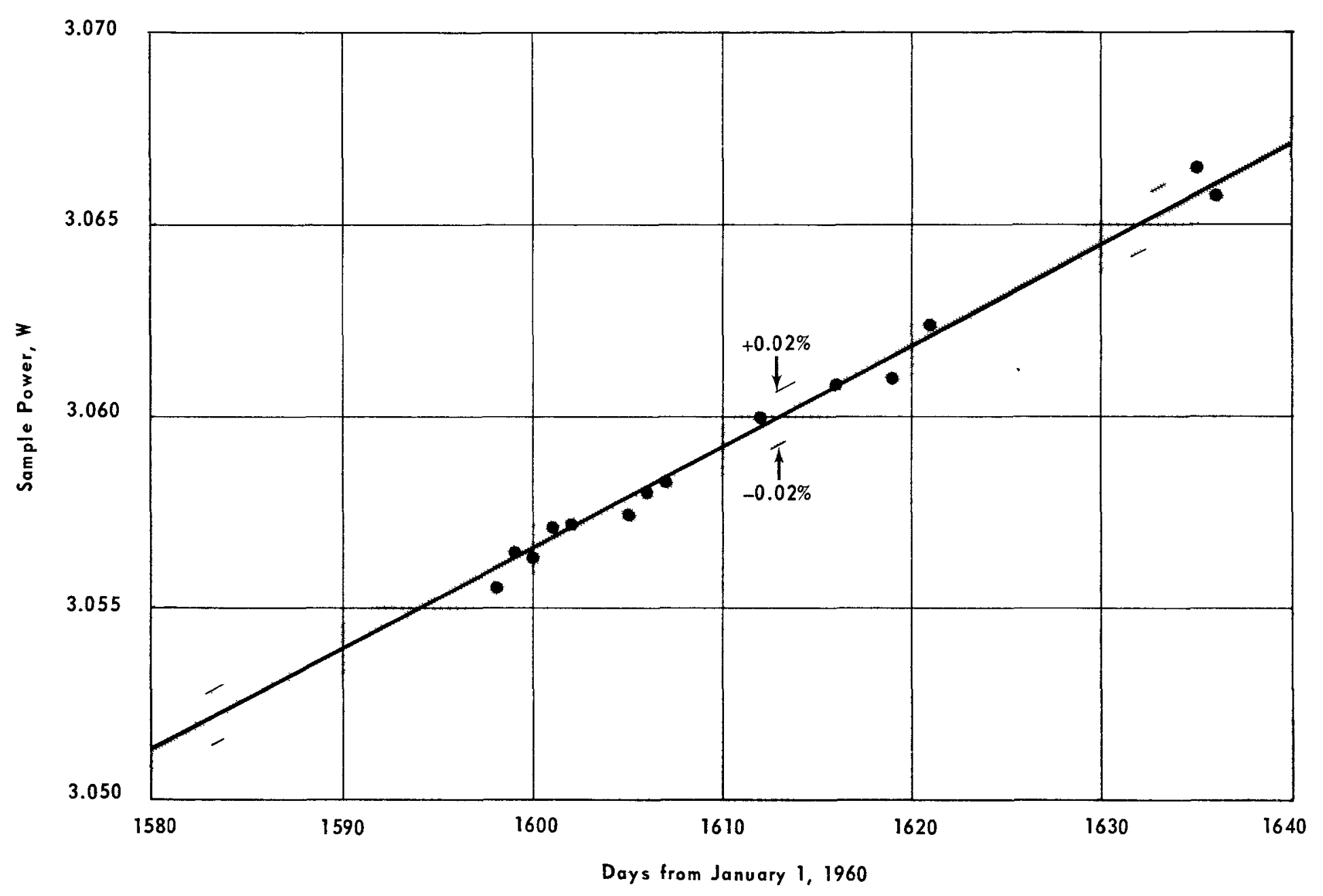


Table 6

CALCULATED LWR SAMPLE POWER AS A FUNCTION OF TIME

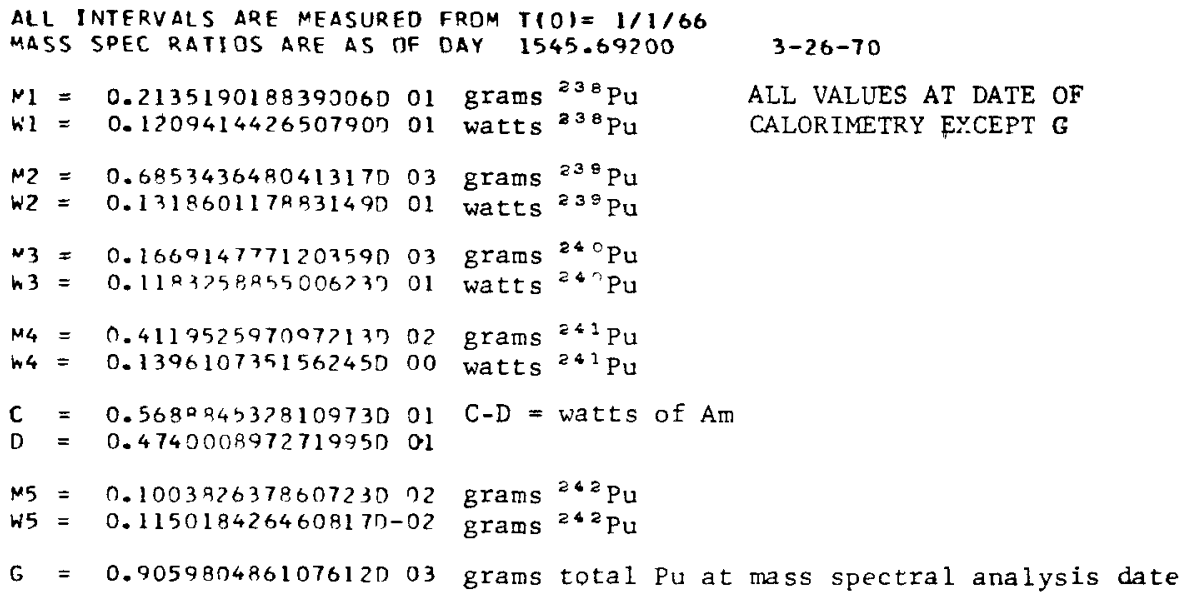

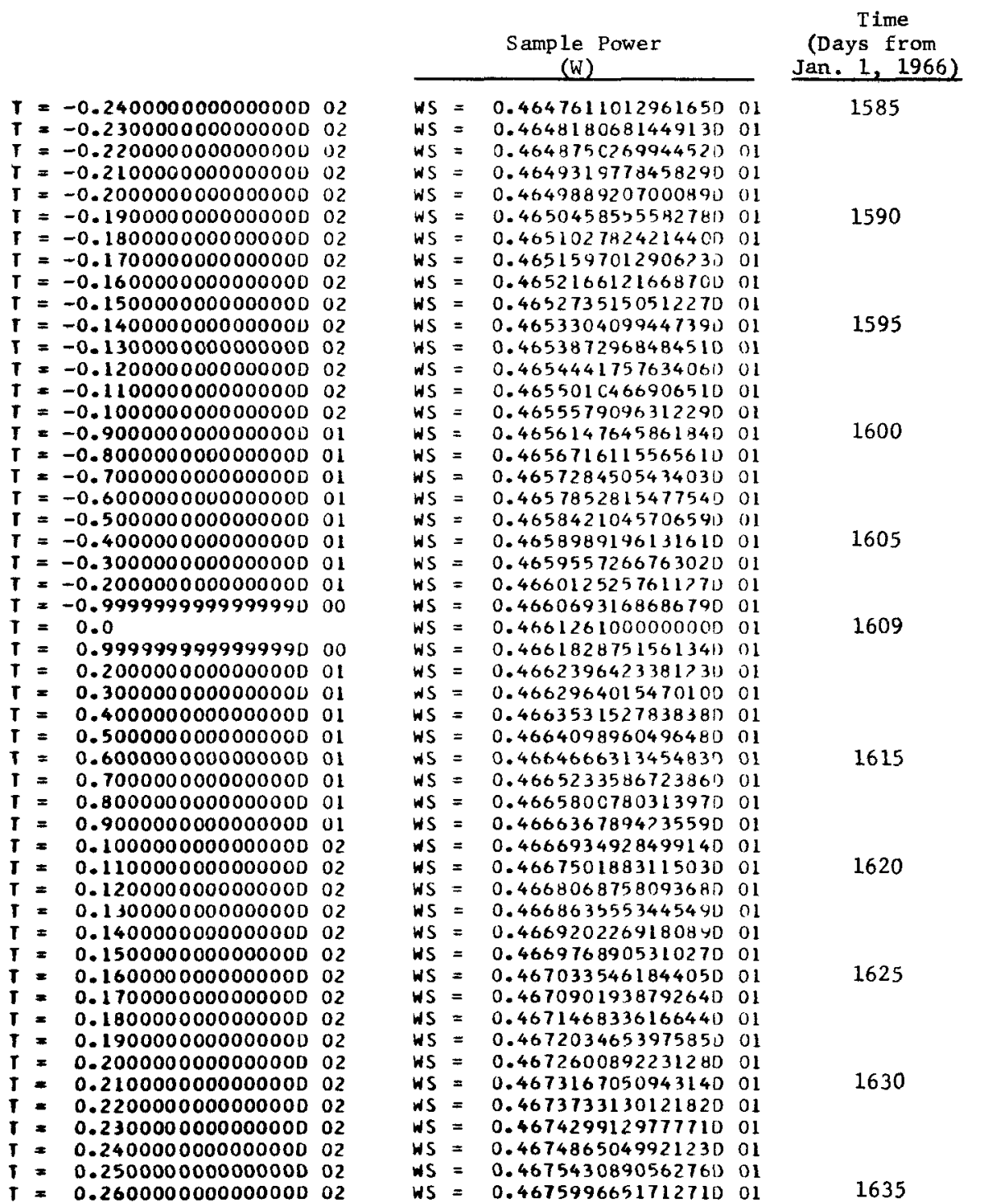


Table 7

CALCULATED FAST REACTOR FEED SAMPLE POWER AS A FUNCTION OF TTME

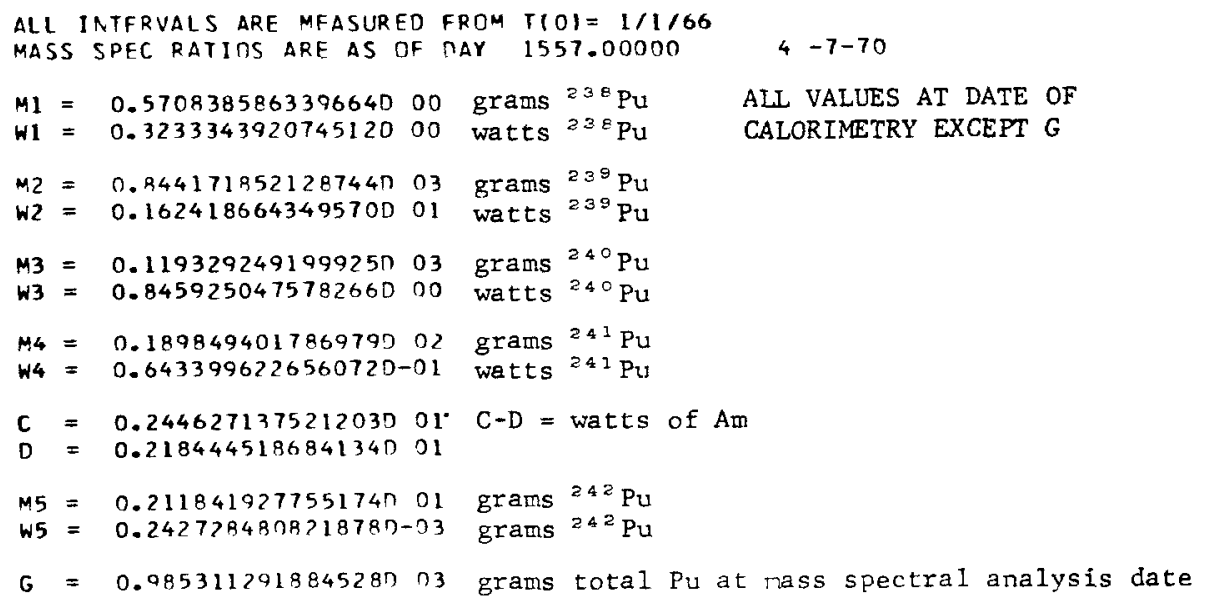

CALORIMETRY EXCEPT G

0.985311291884528 ก 13 grams tota

Sample Power (W)

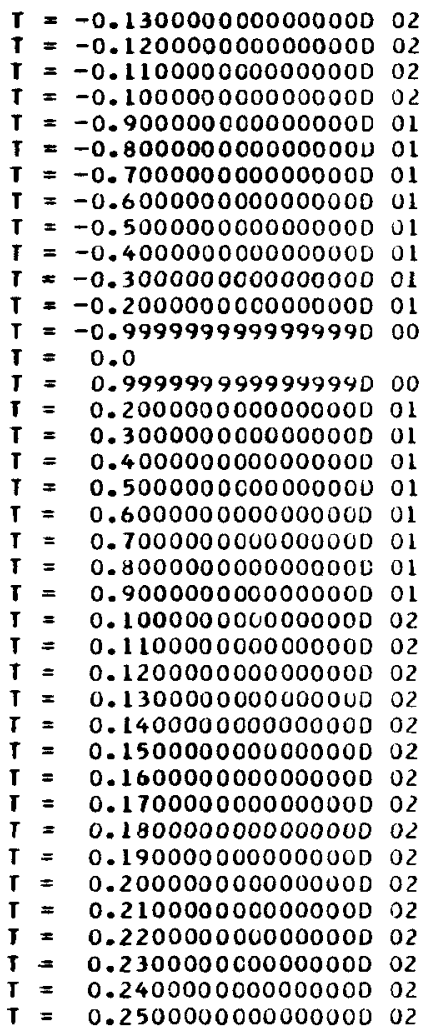

\begin{tabular}{|c|c|c|c|}
\hline & & (W) & \\
\hline & & 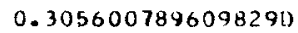 & \\
\hline & & & \\
\hline & $=$ & & \\
\hline & $=$ & & \\
\hline & $=$ & $0 \in 335$ & \\
\hline & $=$ & & \\
\hline & $=$ & & \\
\hline & 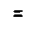 & & \\
\hline & $=$ & & \\
\hline & 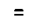 & & \\
\hline & $=$ & & \\
\hline & $=$ & 190 & \\
\hline & $=$ & 1 & \\
\hline & 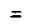 & 943 & \\
\hline & 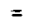 & $\rightarrow 69$ & \\
\hline & $=$ & & \\
\hline & - & & \\
\hline & $=$ & & \\
\hline & $=$ & & \\
\hline & $=$ & 0. & \\
\hline & $=$ & 0 & \\
\hline & $-\mathrm{s}$ & 542 & \\
\hline & & & \\
\hline & 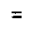 & & \\
\hline & & & \\
\hline & $=$ & & \\
\hline & $=$ & 0 & \\
\hline & $=$ & $u$ & \\
\hline & $=$ & 0. & \\
\hline & $=$ & 0. & \\
\hline & & 0. & \\
\hline & $=$ & 41172 & \\
\hline & & 0 & \\
\hline & & 11 & \\
\hline & $=$ & 540 & \\
\hline & $=$ & 41810 & \\
\hline & $=$ & 310 & \\
\hline & $=$ & & \\
\hline & & 0.3066011254098920 & \\
\hline
\end{tabular}

Time (Days from Jan. 1, 1966)

1600

1605

1611 
Tables 6 and 7 are computer printouts for each sample giving watts and grams of each plutonium isotope as of the calorimetry date and total grams of plutonium (G) as of mass spectrometric analysis date. Also given is sample power versus day (day 1612 = June 1, 1970). This type of printout can be used to give a quick check for shipper-receiver comparisons.

Table 8 gives the comparison of these values with shipper values. The differences ( $+1.1 \%$ for the LWR sample and $-0.5 \%$ for the FRF sample) are less than half of the error possible due to the uncertainty in the mass ratios.

Table 8

COMPARISON OF CALORIMETRY RESULTS WITH SHIPPER VALUES

Sample: $\quad$ LWR $\quad$ FRF

Shipper Value

(grams plutonium): $\quad 896.24 \quad 990.3$

Calorimetry value

(grams plutonium): $\quad 905.98 \quad 985.3$

Difference (grams)

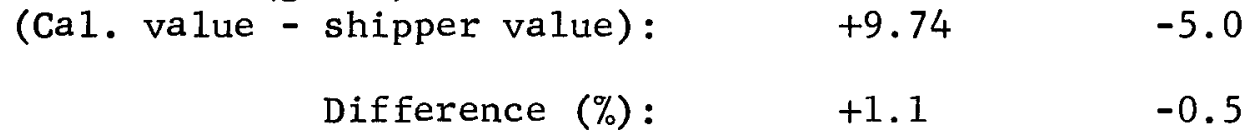

Table 9 gives an estimate of the possible errors for each sample. The error in the plutonium content is included as part of the error in americium concentration. The maximum possible calorimeter error, $0.05 \%$, is considered insignificant and not included. The estimated uncertainties are intended to be representative of industrial facilities. In any case, it is quite clear that the major source of error is uncertainty in the $338 \mathrm{Pu}$ isotopic ratio. ${ }^{3}$ As stated earlier, there are several reasons for this. First, its specific power is 250 times greater than ${ }^{239} \mathrm{Pu}$. Second, the ${ }^{3}{ }^{8} \mathrm{Pu}$ peak is affected by "toe-tailing" from the adjacent, large $238 \mathrm{Pu}$ peak in the mass spectrometry analysis. There is a distinct possibility that the results might be improved by paying more attention to this region of the mass spectrum. The ${ }^{238} \mathrm{Pu}$ abundance can be determined more accurately by performing a separate $\alpha$ pulse height analysis for ${ }^{23} \mathrm{Pu}$. The extent of these limitations is best visualized when one considers that if the uncertainty in the $238 \mathrm{Pu}$ ratio were reduced to $2 \%$, it would still be a larger source of error than all of the other uncertainties combined. 
Table 9

ERROR IN CALORIMETRY ANALYSIS DUE TO UNCERTAINTIES IN ANALYTICAL DATA

\begin{tabular}{|c|c|c|c|c|}
\hline & & & $\begin{array}{c}\text { Estimated } \\
\text { Uncertainty in }\end{array}$ & Potential \\
\hline otope & $\begin{array}{l}\text { Weight } \\
\text { Percent }\end{array}$ & $\begin{array}{r}\text { Heat } \\
(\%)\end{array}$ & $\begin{array}{c}\text { Isotopic Ratio } \\
(\%)\end{array}$ & $\begin{array}{c}\operatorname{Error}^{a} \\
(\%)\end{array}$ \\
\hline
\end{tabular}

LWR Sample

\begin{tabular}{|c|c|c|c|c|}
\hline$a s{ }^{8} \mathrm{Pu}$ & 0.24 & 26.3 & 10 & 2.63 \\
\hline $239 \mathrm{Pu}$ & 75.65 & 28.8 & 0.3 & 0.08 \\
\hline $24{ }^{\circ} \mathrm{Pu}$ & 18.42 & 25.8 & 0.3 & 0.08 \\
\hline a $41 \mathrm{Pu}$ & 4.59 & 3.0 & 1.0 & 0.03 \\
\hline a 4 ₹ $\mathrm{Pu}$ & 1.11 & - & 1.0 & -- \\
\hline $\mathrm{Am}$ & 0.74 & 16.1 & 1.0 & 0.16 \\
\hline TOTAL & 100.74 & 100.0 & & \\
\hline
\end{tabular}

FBR Sample

$\begin{array}{rrccc}238 \mathrm{Pu} & 0.06 & 10.6 & 10.0 & 1.06 \\ 239 \mathrm{Pu} & 85.68 & 53.2 & 0.3 & 0.16 \\ 240 \mathrm{Pu} & 12.11 & 27.7 & 0.3 & 0.08 \\ 241 \mathrm{Pu} & 1.94 & 2.1 & 1.0 & 0.02 \\ 242 \mathrm{Pu} & 0.22 & -- & 1.0 & -- \\ \mathrm{Am} & 0.16 & 6.4 & 1.0 & 0.06 \\ \text { TOTAL } & 100.16 & 100.0 & {\left[\Sigma\left(\mathrm{x}_{\mathbf{i}}\right)^{2}\right]^{\frac{1}{2}}=1.17}\end{array}$

astimated error $=$ Heat $(\%)$ Estimated Uncertainty in Isotopic Ratio (\%). 


\section{CONCLUSIONS}

In conclusion, calorimetry provides a well-established, precise, and nondestructive method for the assay of radioactive materials. Furthermore, high accuracies may be obtained if the radioactive constituents of the sample are well characterized. The sample geometry is such that the entire sample is measured simultaneously. Therefore, the need for taking aliquots is eliminated along with associated errors. Unlike other nuclear nondestructive methods, calorimetry is capable of bulk measurements unaffected by absorption or self-shielding so that sample homogeneity is not a problem. Calorimetry appears to be a very effective method of analysis in cases where the power density is sufficiently high as in $\mathrm{PuO}_{2}$. Current investigations indicate that calorimetry gives fairly good agreement with traditional chemical methods. Further, it might be possible to bypass the usual errors associated with the transfer of large quantities of material by accepting the agreement between the heat output determined by the receiver and that predicted by the shipper. It appears that this would give differences of $0.1 \%$ or less. Improved methods of measuring isotopic ratios, particularly one which would more precisely determine the amount of ${ }^{238} \mathrm{Pu}$, would enable more accurate absolute determination of plutonium quantities. The excellent precision and accuracy shown here suggests that shipper-receiver exchanges be based on measured wattages. It would be extremely difficult for anyone to deliberately circumvent this system by the substitution of material having a different specific activity since this would require knowledge of the date on which the receiver would measure the heat output. Any undetected tampering of this sample would necessitate that the composite total specific powers of the substitute, as well as the rate of change of its specific power, exactly match that of the undisturbed sample. This would hardly be possible unless the constituent isotopes of the substitute were the same as that of the original and further that they were present in the same quantities so as to make the rate of change of the power output identica1. One would hardly want to divert a quantity of fissile material if he had to replace it with the same quantity of identical material in order to prevent the detection of his diversion. 
The applicability of calorimeters to the solution of Safeguards problems will continue to be investigated. The feasibility of using a calorimeter to determine the quantity of plutonium in lots of fuel pellets, platelets and high density scrap will be investigated. The possibility of using calorimeters to ascertain the actual abundances of various isotopes in standard samples will be pursued by analyzing the effect of various isotopic compositions on the rate of change of the sample power. This would permit an independent, absolute, and nondestructive calibration of these standards for use with other nuclear methods of analysis.

The potential use of calorimetry to determine amounts of uranium by inducing fission in a sample residing in the calorimeter will be considered. A preliminary analysis will be made of the quantity of power to be expected from a particular sample and source neutron flux. If this appears to be practical the work will expand to study geometry, packaging and other effects which may limit the accuracy.

Participation in the Plant Instrumentation Program sponsored by the AEC Office of Safeguards and Materials Management will be continued. Calorimeters are being furnished to industrial participants for use in the feed material and scrap phases. In addition, Mound Laboratory will function as consultants to those who are pursuing this type of analys is. 
- 
APPENDIX 
MANUAL CALCULATION OF PLUTONIUM CONTENT IN LWR AND FBR FUEL SAMPLES

The exact calculation of plutonium content from calorimetry date requires the isotopic ratios first be decayed from the mass spectral analysis date to the calorimetry date. Then the mass ratios multiplied by the specific power are summed to give a weighted specific power of the sample in terms of watts per gram of plutonium. This value is then divided into the total power to give total grams at the date of isotopic analysis. The following involves a manual calculation of the plutonium content in an LWR sample

First, the americium concentration is normalized to plutonium content:

$$
\frac{\text { Am Concentration }}{\text { Plutonium Content }}=\frac{0.006334}{0.8636}=0.007334 \mathrm{~g} \text { of Am } / \mathrm{g} \text { of } \mathrm{Pu} \text {. }
$$

Next, each Pu isotopic ratio is decayed 63 days and the normalized Am concentration 78 days to the calorimetry date. To simplify this, Table A-1 shows $e^{-\lambda t}$ versus time for LWR and FBR samples. For four figure accuracy, it is not necessary to decay the isotopic ratios for ${ }^{3.9} \mathrm{Pu}$, $24{ }^{\circ} \mathrm{Pu}$ and $248 \mathrm{Pu}$. For $238 \mathrm{Pu}$ and $\mathrm{Am}$, first determine the number of days, months and years the sample is to be decayed. Next, find the decay factor $\left(e^{-\lambda t}\right)$ on each table and multiply them together for the total decay. For example, to decay ${ }^{241} \mathrm{Pu} 65$ days (2 months and 5 days):

$$
e^{-\lambda t}=0.992037 \times 0.999344=0.991386
$$

Also included in Table $\mathrm{A}-1$ is a section giving the approximate amount of americium which grows in as a function of time due to the $\beta$-decay of $241 \mathrm{Pu}$. This should be calculated from the date of the americium analysis to include the amount which grows between the mass spectral analysis and americium analysis. To obtain the amount of $241 \mathrm{Pu}$ which was present during americium analysis, it is necessary to back decay its isotopic ratio 15 days. This can be done by taking the decay factor for 15 days from the ${ }^{24} \mathrm{Pu}$ section in Table $A-1$ and dividing it into the isotopic ratio.

$$
\text { 241 } \begin{aligned}
\mathrm{Pu} \text { at americium analysis } & =\frac{2{ }^{41} \mathrm{Pu} \text { at mass spec }}{\left(\mathrm{e}^{-\lambda \mathrm{t})}\right.} \\
& =\frac{0.04585}{0.998032} \\
& =0.04594
\end{aligned}
$$

The amount of americium which has grown in since americium analysis can be calculated from the following equation:

$$
\frac{N_{2}}{N_{1}^{0}}=\frac{\lambda_{1}}{\lambda_{2}-\lambda_{1}}\left[e^{-\lambda_{1} t}-e^{-\lambda_{2} t}\right]
$$


The ratio of ingrown ${ }^{241} \mathrm{Am}$ to ${ }^{241} \mathrm{Pu}$ present at day zero is $\mathrm{N}_{2} / \mathrm{N}_{1}$ and is computed in terms of days, months and years in Table A-1 at the end of this appendix. Here the factors are additive rather than multiplicative. For example, for 78 days after americium, add the factor for two months (60.9 days) to the factor for 17 days.

$$
\frac{\mathrm{N}_{2}}{\mathrm{~N}_{1}}=0.00796+0.00223=0.01019
$$

Table A-2 gives a summary of the $\mathrm{Pu}$ isotopic ratio calculation in the LWR sample. An additional example using the FBR sample is summarized in Table $\mathrm{A}-3$. 
Table A-1

DECAY FACTORS $\left(e^{-\lambda t}\right)$ FOR VARIOUS ISOTOPES IN LWR AND FBR FUEL SAMPLES

\begin{tabular}{|c|c|}
\hline Years & $230 \mathrm{Pu}$ \\
\hline $\begin{array}{r}1 \\
2 \\
3 \\
4 \\
5 \\
6 \\
7 \\
8 \\
9 \\
10\end{array}$ & $\begin{array}{l}.99213378 \\
.98432945 \\
.97658651 \\
.96890447 \\
.96128286 \\
.95372121 \\
.94621904 \\
.93877588 \\
.93139127 \\
.92406475\end{array}$ \\
\hline Months & \\
\hline 1 & .99934210 \\
\hline 2 & .99868464 \\
\hline 3 & .99802761 \\
\hline 4 & .99737102 \\
\hline 5 & .99671486 \\
\hline 6 & .99605912 \\
\hline 7 & .99540382 \\
\hline 8 & .99474895 \\
\hline 9 & .99409452 \\
\hline 10 & .99344051 \\
\hline 11 & .99278693 \\
\hline 12 & .99213378 \\
\hline
\end{tabular}

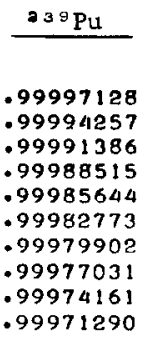

.99989398

.99979798

.99968199

.99968199

.99957601

.99947004

.99936409

.99915221

.99894037

$\frac{241 \mathrm{Pu}}{}$
.95316365
.90852095
.86596915
.82541032
.78675112
.74990257
.71477998
.68130220
.64939250
.61897733

$241 \mathrm{Am}$

Ingrowth

${ }^{21} \mathrm{Am}$
.99839937
.99680130
.99520579
.99361283
.99202243
.99043457
.98884925
.98726647
.98568622
.98410850

.04679855

.09133032

- 13370159

- 17401369

- 1236316

- 1236316

.28353811

.31653493

.34791224

.37774598

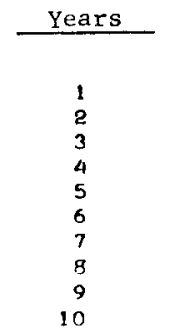

Months

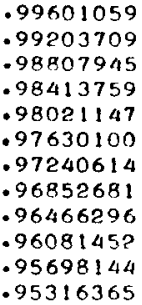

.99986651 .99973305

. 99959960 .99946617 . 99933275

.09019936

.99906598

.99893262

99879928

.99866596

.99853265

.99839937

.00398914 .00796183

.01191815

- 01585815

.01978190

.02368946

.02758090

.03145629

.03531568

.03915915

.04298675

.04679855
.99986867 .99973736 .99960607 - 99947480

.99934354

-999?1230

-99908108

.99894988

.99881869

.99868752

.99855637

.99842523

.99829411

.99816301

- 99803193

.99790086

.99776981

.99763878

.99750776

.99737676

.99724578

.99711482

.99698387

.99685294

.99672203

.99659114

.99646026

. 99632940

.99619856

.99606773

\begin{tabular}{|c|c|}
\hline .00013132 & 1 \\
\hline .00026263 & 2 \\
\hline .00039392 & 3 \\
\hline .00052519 & $\Delta$ \\
\hline .00065644 & 5 \\
\hline .00078768 & 6 \\
\hline .00091890 & 7 \\
\hline .00105010 & 8 \\
\hline .00118128 & 9 \\
\hline .00131244 & 10 \\
\hline .00144359 & 11 \\
\hline .00157472 & 12 \\
\hline .00170583 & 13 \\
\hline .00183692 & 14 \\
\hline .00196800 & 15 \\
\hline .00209906 & 16 \\
\hline .00223010 & 17 \\
\hline .00236112 & 18 \\
\hline .00249212 & 19 \\
\hline .00262311 & 20 \\
\hline .00275408 & 21 \\
\hline .00284503 & 22 \\
\hline .00301596 & 23 \\
\hline $.003146 R 8$ & 24 \\
\hline .00327778 & 25 \\
\hline .00340866 & 26 \\
\hline .00353952 & 27 \\
\hline .00357037 & 28 \\
\hline .00380119 & 29 \\
\hline .00393200 & 30 \\
\hline
\end{tabular}


Table A-2

\section{LWR PLUTONIUM HAND CALCULATION}

\begin{tabular}{|c|c|c|c|c|}
\hline Isotope & $\begin{array}{l}\text { Mass Ratio } \\
\left(R_{1}\right) \\
\end{array}$ & $\begin{array}{c}\text { Specific Power } \\
\left(F_{1}\right)\end{array}$ & $\begin{array}{c}\text { Decay Factor } \\
\left(e^{-\lambda_{i}}\right) \\
\end{array}$ & $R_{1} F_{1} e^{-\lambda} i t$ \\
\hline $238 \mathrm{Pu}$ & 0.00236 & 0.56642 & 0.998598 & 0.0013349 \\
\hline $239 \mathrm{Pu}$ & 0.75647 & 0.001924 & 1.0000 & 0.0014554 \\
\hline $24 \circ \mathrm{Pu}$ & 0.18424 & 0.007089 & 1.0000 & 0.0013061 \\
\hline$a \leq 1 \mathrm{Pu}$ & 0.04585 & 0.003389 & 0.991516 & 0.0001541 \\
\hline $242 \mathrm{Pu}$ & 0.01108 & 0.0001146 & 1.0000 & 0.0000013 \\
\hline$a^{4} \mathrm{I} \mathrm{Am}$ & 0.007334 & 0.1145 & 0.999734 & 0.0008395 \\
\hline Ingrowth Am & 0.04594 & 0.1145 & 0.01045 & 0.0000550 \\
\hline
\end{tabular}

$\mathrm{Pu}$ Content $=\frac{\text { Av. Calorimeter Value (watts) }}{\text { Specific Power of Sample }}=\frac{4.6613}{0.0051463}=905.8 \mathrm{~g}$

Calorimetry date $=63$ days after mass spectral analysis and 78 days after americium analysis.

Table A-3

FBR PLUTONIUM HAND CALCULATION

\begin{tabular}{|c|c|c|c|c|}
\hline Isotope & $\begin{array}{l}\text { Mass Ratio } \\
\left(R_{i}\right) \\
\end{array}$ & $F_{1}$ & $e^{-\lambda t}$ & $R_{i} F_{i} e^{-\lambda_{i} t}$ \\
\hline 2 $38 \mathrm{Pu}$ & 0.00058 & 0.56642 & 0.9987 & 0.0003281 \\
\hline a $39 \mathrm{Pu}$ & 0.85676 & 0.001924 & 1.0000 & 0.0016484 \\
\hline $24^{\circ} \mathrm{Pu}$ & 0.12111 & 0.007089 & 1.0000 & 0.0008585 \\
\hline$a^{4} \perp \mathrm{Pu}$ & 0.01940 & 0.003389 & 0.9915 & 0.0000652 \\
\hline${ }^{2} 42 \mathrm{Pu}$ & 0.00215 & 0.000115 & 1.0000 & 0.0000002 \\
\hline Am & 0.001579 & 0.1145 & 0.9996 & 0.0001807 \\
\hline Am Ingrowth & 0.01944 & 0.1145 & 0.01045 & $\frac{0.0000233}{0.0031044}$ \\
\hline
\end{tabular}

Calorimetry date $=65$ days after mass spectral analyses and 80 days after americium analyses. 


\section{REFERENCES}

1. P. Curie and A. Laborde, Compt. Rend., 136, 673 (1903).

2. E. Rutherford and H. T. Barnes, Nature, 68, 622 (1903).

3. AVCO Mass Spectrometer Services, AVCO Electronics Division, Tulsa, Oklahoma, (May 19, 1969) p. 6.

4. D. Gupta, Proceedings of the AEC Symposium on Safeguards Research and Development, WASH 1147 (October 1969) p. 154.

5. H. W. Kraner, Use of Gamma Ray Spectron to Determine Pu Isotopic Abundance in Pu Sources, BNL-50237 (May 1970).

6. J. E. C1ine, E. B. Nieschmidt, A. L. Conne11y, and E. L. Murri, A Technique for Assay of L-10 Bottles of Plutonium Nitrate, IN-1433 (October 1970).

7. G. W. Otto, Principles of Operation Model 105 Calorimeters SN-118 and SN-119, Mound Laboratory Technical Manua 1 MD-20811 (October 2, 1968).

8. K. C. Jordan, "Calorimetric Ha1f-Life of Plutonium-238", Mound Laboratory Progress Report for Chemistry: July September, 1967, MLM-1443, (March 29, 1968) pp. 11-30.

9. R. Sher, Ha1f-Lives of ${ }^{3} \mathrm{H}$ and ${ }^{238} \mathrm{Pu}, \mathrm{BNL}-50233(\mathrm{~T}-570)$, 1970 .

10. J. T. Byrne, C. E. Caldwe11, R. L. Delaney, J. D. Moseley and F. L. Oetting, Measurements Involved in Shipping Plutonium Oxide, RFP-502 (August 10, 1965).

11. F. L. Oetting and S. R. Gunn, J. of Inorg. Nuc1. Chem., 29,2659 (1967).

12. S. R. Gunn, "Radiometric Calorimetry - A Review," Nuc1. Instr. Meth., 29, 1-24 (1964). Also see Supplement, 85, 285-312 (1970).

P. F. Carpenter, Editor 